\title{
Proteasomal Inhibition Redirects the PrP-Like Shadoo Protein to the Nucleus
}

\author{
Sang-Gyun Kang ${ }^{1,2} \cdot$ Charles E. Mays $^{1} \cdot$ Nathalie Daude $^{1} \cdot$ Jing Yang $^{1} \cdot$ Satyabrata Kar $^{1} \cdot$ David Westaway $^{1,2,3}$ D
}

Received: 17 January 2019 / Accepted: 24 April 2019 / Published online: 25 May 2019

(C) The Author(s) 2019

\begin{abstract}
The Shadoo protein (Sho) exhibits homology to the hydrophobic region of the cellular isoform of prion protein (PrP $\mathrm{C}^{\mathrm{C}}$ ). As prioninfected brains gradually accumulate infectivity-associated isoforms of prion protein $\left(\mathrm{PrP}^{\mathrm{Sc}}\right)$, levels of mature endogenous Sho become reduced. To study the regulatory effect of the proteostatic network on Sho expression, we investigated the action of lactacystin, $\mathrm{MG} 132, \mathrm{NH}_{4} \mathrm{Cl}$, and 3-methyladenine (3-MA) in two cell culture models. In primary mixed neuronal and glial cell cultures (MNGCs) from transgenic mice expressing wild-type Sho from the PrP gene promoter (Tg.Sprn mice), lactacystin- and MG132-mediated inhibition of proteasomal activity shifted the repertoire of Sho species towards unglycosylated forms appearing in the nuclei; conversely, the autophagic modulators $\mathrm{NH}_{4} \mathrm{Cl}$ and 3-MA did not affect Sho or PrP $\mathrm{Plycosylation}^{\mathrm{C}}$ patterns. Mouse N2a neuroblastoma cells expressing Sho under control of a housekeeping gene promoter treated with MG132 or lactacystin also showed increased nuclear localization of unglycosylated Sho. As two proteasomal inhibitors tested in two cell paradigms caused redirection of Sho to nuclei at the expense of processing through the secretory pathway, our findings define a balanced shift in subcellular localization that thereby differs from the decreases in net Sho species seen in prion-infected brains. Our data are indicative of a physiological pathway to access Sho functions in the nucleus under conditions of impaired proteasomal activity. We also infer that these conditions would comprise a context wherein Sho's N-terminal nucleic acid-binding RGG repeat region is brought into play.
\end{abstract}

Keywords Nuclear localization · Proteasomal inhibition · Proteostasis · Impaired ER import · Neurons and glia

\section{Introduction}

Prion infections result in a conformational remodeling of the cellular isoform of the prion protein called $\operatorname{PrP}^{\mathrm{C}}$, yielding a beta-sheet enriched and infectivity-associated isoform denoted $\mathrm{PrP}^{\mathrm{Sc}}$ [1]. In support of this concept, subtle mutations in the prion protein gene (Prnp) in mice impact disease progress and

Electronic supplementary material The online version of this article (https://doi.org/10.1007/s12035-019-1623-1) contains supplementary material, which is available to authorized users.

David Westaway

david.westaway@ualberta.ca

1 Centre for Prions and Protein Folding Diseases, University of Alberta, 204 Brain and Aging Research Building,

Edmonton, Alberta T6G 2M8, Canada

2 Division of Neurology, University of Alberta, Edmonton, Alberta, Canada

3 Department of Biochemistry, University of Alberta, Edmonton, Alberta, Canada pathology [2-4]. $\operatorname{PrP}^{\mathrm{C}}$ knockout mice $\left(\operatorname{Prnp}^{0 / 0}\right)$ have normal development and are completely resistant to prion infections [5]. Given $\operatorname{PrP}^{\mathrm{C}}$ 's conservation (catalogued by Wopfner et al. [6]), the viability of homozygous null mice was in some regards surprising [7] and provoked the hypothesis of a cryptic functional homolog [8]. Subsequent to these speculations, the Shadoo protein (Sho) gene (Sprn) was found by its homology to the $\operatorname{PrP}^{\mathrm{C}}$ 's central hydrophobic region [9]. Further work established fish and mammalian Sho are glycoproteins synthesized in the secretory pathway and attached to the external face of the plasma membrane via a glycosylphosphatidylinositol (GPI) anchor [10, 11]. Sho is expressed in the mouse central nervous system (CNS) in regions that partially overlap with $\operatorname{PrP}^{\mathrm{C}}$ expression and the two proteins share a number of binding partners in common. Despite these similarities, double knockout $\operatorname{Sprn}^{0 / 0}+\operatorname{Prnp}^{0 / 0}$ mice are viable $[12,13]$, suggesting that Sho is not a functional homolog of $\mathrm{PrP}^{\mathrm{C}}$ or that other homologs exist in the mouse genome.

Refolding and aggregation are touchstones in PrP biology and, notably, natively disordered recombinant Sho (amino acids 25-122) has a propensity to aggregate to a proteaseresistant form in vitro $[14,15]$. Protease resistance of full- 
length Sho also has been reported in mammalian cells under certain conditions interfering with proteostasis [16]. In prion infections where proteinase $\mathrm{K}$-resistant isoforms of $\operatorname{PrP}^{\mathrm{Sc}}$ $\left(\right.$ resPrP $\left.{ }^{\mathrm{Sc}}\right)$ are accumulating and where protein degradation mechanisms have an extra burden, the levels of mature Sho do not increase. Rather, they decrease [11, 17-19], with a similar effect being deduced for $\operatorname{PrP}^{\mathrm{C}}$ [20]. These parallel findings raise the broader question of the concerted proteostatic systems relevant to the reduction of both Sho and $\operatorname{PrP}^{\mathrm{C}}$. However, the work in this area encompasses diverse and sometimes conflicting findings.

Causal roles of the altered Sho regulation following prion infection have been attributed to glycosylation, in mediating stable expression, and the proteasomal pathway in degrading unglycosylated Sho $[16,21]$. Alternative subcellular targeting may be an important variable in this mechanism. There is extensive literature concerning a leaky signal peptide for $\operatorname{PrP}^{\mathrm{C}}$ that does not always engage the endoplasmic reticulum (ER) translocon [22-25]. Sho is reported to be directed to mitochondria under conditions of an impaired ER import [26] and ShoYFP fusion proteins have been reported in the nucleus in a number of different cell lines under resting conditions [27]; this latter situation could arise from the use of nuclear targeting signals that apply to proteins synthesized from cytoplasmic ribosomes. Untagged wild-type Sho has been demonstrated in the nucleus as well as in membrane fractions in sequential purifications of mouse brain samples [13].

To tackle these diverse results and the question of proteostasis for the mammalian prion protein family, we have used experimental systems that include primary mixed neuronal and glial cell cultures (MNGC's) and immortalized neuroblastoma cells expressing Sho (N2a-Sprn). Our studies reveal glycosylation state as an indicator (rather than a determinant) of cellular decision to induce nuclear localization of Sho under conditions of proteasomal inhibition. These data align with the nucleic acid binding and subcellular targeting properties of Sho's RGG repeat region [27-29] and offera basis for understanding divergent aspects of Sho and $\mathrm{PrP}^{\mathrm{C}}$ biology defined by genetic studies $[13,30,31]$.

\section{Materials and Methods}

\section{Cell Cultures: Mixed Neuronal and Glial Cell Culture, and N2a-Sprn}

Primary mixed neuronal and glial cell cultures (MNGCs) were prepared from both transgenic mice expressing full-length Shadoo protein (Sho) $\left(\mathrm{Tg} . \mathrm{Sprn}^{+/}\right.$) and Sho knockout mice $\left(\mathrm{Sprn}^{0 / 0}\right)$ [30] as described previously [32]. All animal handling protocols were in accordance with Canadian Council on Animal Care and University of Alberta institutional ethics review (protocol AUP00000356). One day before the culture, genomic DNA of the transgenic mice was extracted from toe snips and genotyped for the presence or absence of the Sprn transgene by polymerase chain reaction (PCR) using the following primer pairs. 3'UTR forward: 5'-TCGA TCCAGAGCCTTTGAATTGAG-3' and 3'UTR reverse: $5^{\prime}$ GGGTGAAATGGTCAGTGCATTACG- $3^{\prime}$. The next day, MNGCs were extracted from cerebella of 8-day-old pups $\left(\mathrm{Tg} . \mathrm{Sprn}^{+/-}\right.$and $\mathrm{Sprn}^{0 / 0}$ ) by mechanical and enzymatic dissociation with trypsin. The cells were plated on plastic culture dishes coated with $10 \mu \mathrm{g} / \mathrm{mL}$ poly-L-lysine (PLL, SigmaAldrich, MO, USA, P4707) at $1 \times 10^{6}$ cells/well in a sixwell plate. The cells were maintained at $37{ }^{\circ} \mathrm{C}$ with $5 \% \mathrm{CO}_{2}$ in minimum essential medium (MEM, Sigma-Aldrich, M4655), supplemented with $10 \%$ fetal bovine serum (FBS, Gibco, 12438), $25 \mathrm{mM} \mathrm{KCl}$, and penicillin-streptomycin (Gibco, MA, USA, 15140). For serum starvation, the cells were not supplemented with FBS for $16 \mathrm{~h}$.

Murine neuroblastoma cells, N2a (ATCC, VA, USA, CCL131 ), and chronically prion-infected $\mathrm{N} 2 \mathrm{a}[33,34]$ were maintained at $37{ }^{\circ} \mathrm{C}$ with $5 \% \mathrm{CO}_{2}$ in Dulbecco's modified Eagle's medium (DMEM) with high glucose $(4.5 \mathrm{~g} / \mathrm{L})$ and $2 \mathrm{mM}$ glutamine (Gibco, 11995-065), supplemented with 10\% FBS and penicillin-streptomycin. The coding region for full-length wild-type Sho (Sprn) was cloned into a mammalian expression vector, pBudCE4.1 (Invitrogen, CA, USA, V532-20), in which Sho expression was driven either by a human elongation factor 1 alpha $(\mathrm{EF}-1 \alpha)$ promoter or by a cytomegalovirus (CMV) promoter. N2a cells were transfected with the Sprn constructs using Lipofectamine 2000 reagent (Invitrogen, 11668) and stable cell clones were obtained by zeocin (Invitrogen, R250) selection. To determine Sho expression, the transfectants were harvested and lysed in RIPA lysis buffer (1\% Triton X-100, $1 \%$ sodium deoxycholate, $150 \mathrm{mM} \mathrm{NaCl}$, $50 \mathrm{mM}$ Tris-HCl, pH 7.4, 0.1\% SDS, 1 mM EDTA) containing a protease inhibitor cocktail (Roche, 04693159 001).

\section{Modulation of the Intracellular Proteolytic System}

MNGCs (at 7 days in vitro culture) and N2a-Sprn (at second passage) were treated with modulators targeting proteolytic system, with conditions specified as per figure legends. These modulators included lactacystin (Sigma-Aldrich, L6785), MG132 (Selleck Chemicals, TX, USA, S2619), $\mathrm{NH}_{4} \mathrm{Cl}$ (Sigma-Aldrich, 213330), and 3-methyladenine (3MA, Sigma-Aldrich, M9281), and innate immune ligands including lipopolysaccharide (LPS, Sigma-Aldrich, L5668) and polyinosinic:polycytidylic acid (poly I:C, Sigma-Aldrich, P1530). The cells were then harvested with RIPA lysis buffer containing a protease inhibitor cocktail.

\section{Western Blot}

The protein concentration of cell lysates was measured by BCA protein assay (Pierce, MA, USA, 23235). To detect 
unglycosylated forms of Sho and cellular isoform of the prion protein $\left(\operatorname{PrP}^{\mathrm{C}}\right), \mathrm{N}$-linked glycans were removed by PNGase $\mathrm{F}$ treatment ( 25 units $/ \mu \mathrm{L}$, New England Biolabs, MA, USA, P0704) at $37^{\circ} \mathrm{C}$ for $1 \mathrm{~h}$. The samples were resolved on $15 \%$ Tris-Glycine gels or NuPAGE Bis-Tris gels (Invitrogen, NP0343) and transferred to PVDF membrane (Thermo Fisher Scientific, MA, USA, 88518). The membrane was blocked with $2 \%$ bovine serum albumin (BSA, Darmstadt, Germany, 2960) in TBST (TBS with $0.1 \%$ Tween 20) and probed with monoclonal $(\mathrm{mAb})$ or polyclonal $(\mathrm{pAb})$ antibodies at $4{ }^{\circ} \mathrm{C}$ overnight: anti-Sho pAb, 06SH1 [11]; anti-PrP mAb, Sha31 (Spibio, France, A03213); anti-ubiquitin pAb (Santa Cruz, TX, USA, sc-9133); anti-lysosomalassociated membrane protein 1 (Lamp-1) pAb (Abcam, Cambridge, UK, ab24170); anti-microtubule-associated protein 1A/1B-light chain 3 (LC3) pAb (MBL, Nagoya, Japan, PM036); anti-glyceraldehyde 3-phosphate dehydrogenase (GAPDH) mAb (Abcam, ab9484); anti-histone $\mathrm{H} 3 \mathrm{pAb}$ (Abcam, ab1791); anti-heat shock protein 60 (Hsp60) pAb (Abcam, ab46798); anti- $\beta$-actin $\mathrm{mAb}$ (Abcam, ab20272). Anti-mouse or anti-rabbit IgG antibodies conjugated to horseradish peroxidase (BioRad, CA, USA, 170-6516 and 170-6515) or alkaline phosphatase (Promega, MI, USA, S327B or S323B) were used as the secondary antibodies and visualized by detecting chemiluminescence (Pierce, 32209) or fluorescence (Promega, S1000) signals. The membrane was stripped in western blot stripping buffer (Thermo Fisher Scientific, 46430) and re-probed as needed.

\section{Immunocytochemistry}

Cells were plated on PLL-coated microscope cover glass (Thermo Fisher Scientific, 12-545-83) or SlideFlasks (Nunc, NY, USA, 170920). For immunocytochemistry, cells were fixed in paraformaldehyde (4\%, $\mathrm{pH} 7.4$ ) for $15 \mathrm{~min}$ and optionally permeabilized with PBS containing Triton X-100 $(0.1 \%)$. The fixed cells were blocked with $1 \%$ BSA in PBST (PBS with $0.1 \%$ Tween 20) for $30 \mathrm{~min}$ and probed with $\mathrm{mAb}$ or pAb at $4{ }^{\circ} \mathrm{C}$ overnight: anti-Sho pAb, 06SH1 and 06SH3 [11]; anti-PrP mAb, SAF83 (Cayman, MI, USA, 189765); anti-microtubule-associated protein 2 (MAP2) pAb (Abcam, ab5392). To visualize the target molecules, cells were then incubated with appropriate fluorescent-conjugated secondary antibodies (Alexa Fluor 488 or Alexa Fluor 594, Invitrogen). Counterstaining for nuclei was performed with Hoechst 33342 (Invitrogen, H1399). Cells were then imaged by a confocal microscopy (LSM700 laser scanning microscope, Zeiss, Jena, Germany) with Z-stack functions under identical imaging settings. The images were analyzed by Zen 2010b SP1 imaging software (Zeiss) and ImageJ (https://imagej.nih.gov/ij/).

\section{Subcellular Fractionation}

To determine the translocation of target molecules, nuclear and cytoplasmic extracts were prepared using NE-PER Nuclear and Cytoplasmic Extraction Reagents (Thermo Fisher Scientific, 78833) following the manufacturer's instructions. Cells were harvested after trypsinization for cell counting. Then, input materials were normalized by pelleting $2 \times 10^{6}$ cells from each treatment. Cell membranes were disrupted by addition of the first detergent. Cytoplasmic extracts were recovered by centrifugation and the nuclei were then lysed with a second detergent to yield nuclear extracts. The purities of the extracts were determined by western blot probed with anti-GAPDH mAb (Abcam, ab9484) and antihistone $\mathrm{H} 3$ pAb (Abcam, ab1791).

\section{Statistical Analysis}

The number of independent experiments or biological replicates of compared groups was at least $n=2$ for each observation. Statistical analysis for western blot results was performed using the independent sample $t$ test and one-way analysis of variance (ANOVA) followed by post hoc Tukey's honest significant difference (HSD) test. Statistical analysis of all data was performed using PRISM (GraphPad Software, CA, USA) version 5 software.

\section{Results}

\section{Proteasomal Inhibition and Sho Expression in MNGCs}

Sho and the cellular isoform of prion protein $\left(\mathrm{PrP}^{\mathrm{C}}\right)$ differ in their configuration of $\mathrm{N}$-terminal natively disordered sequences-Sho contains RGG repeats, while $\operatorname{PrP}^{\mathrm{C}}$ contains PHGGGWGQ metal-binding octarepeats (Fig. 1a) [9, 11]. Downregulation of glycosylated forms of Sho is a preclinical molecular signature of prion diseases [11, 18-20]; however, the cellular mechanism remains unclear. To test the more general question as to whether inhibition of proteolytic systems causes Sho downregulation, four modulators targeting the proteostatic network were tested in MNGCs from Tg.Sprn (Tg.Sprn-MNGC) and $S p r n^{0 / 0}$ knockout mice $\left(S p r n^{0 / 0}\right.$ MNGC): (1) lactacystin which modifies the 20S proteasome subunit $\beta 5$ and irreversibly blocks its activity [35], (2) MG132 that reduces degradation of ubiquitinated proteins through the $26 \mathrm{~S}$ proteasome by interfering with catalytic activity [36], (3) $\mathrm{NH}_{4} \mathrm{Cl}$ which attenuates lysosomal acidification, causing a reduction in lysosome-mediated protein degradation and disruption of autophagolysosome formation [37] and (4) 3-methyladenine (3-MA) that inhibits type III phosphoinositide 3-kinase (PI-3K) and thereby attenuates formation of phagophores [38]. 
a

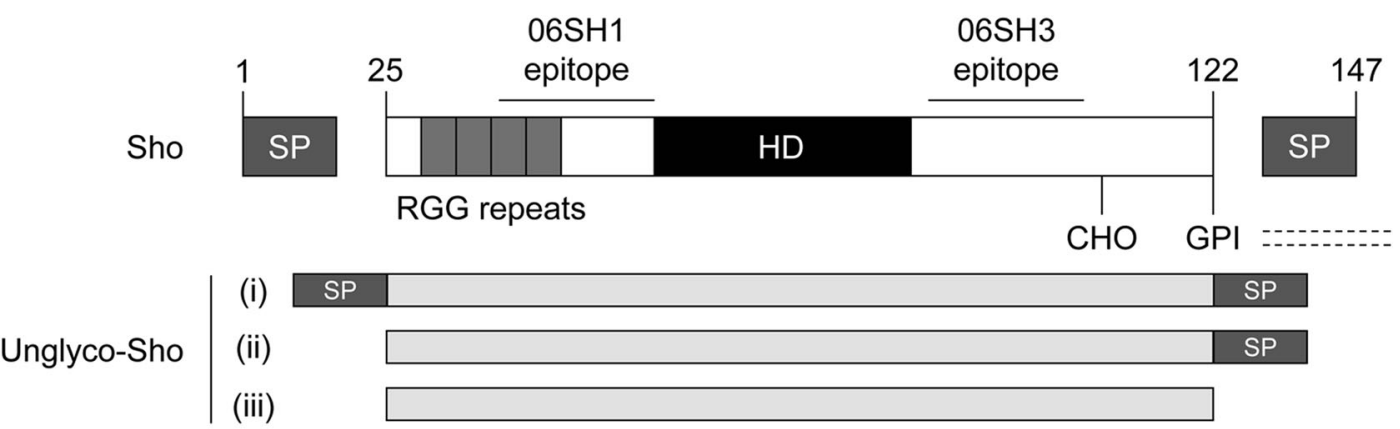

b

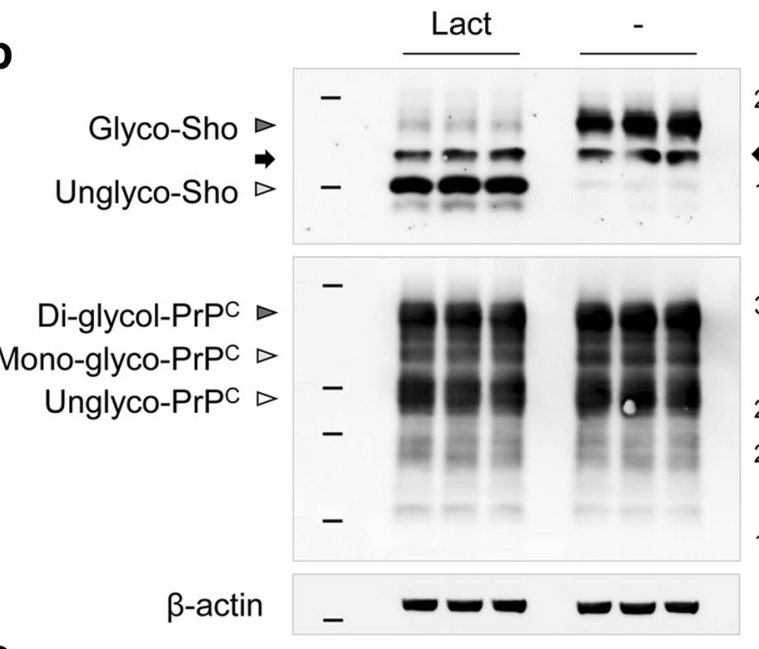

C
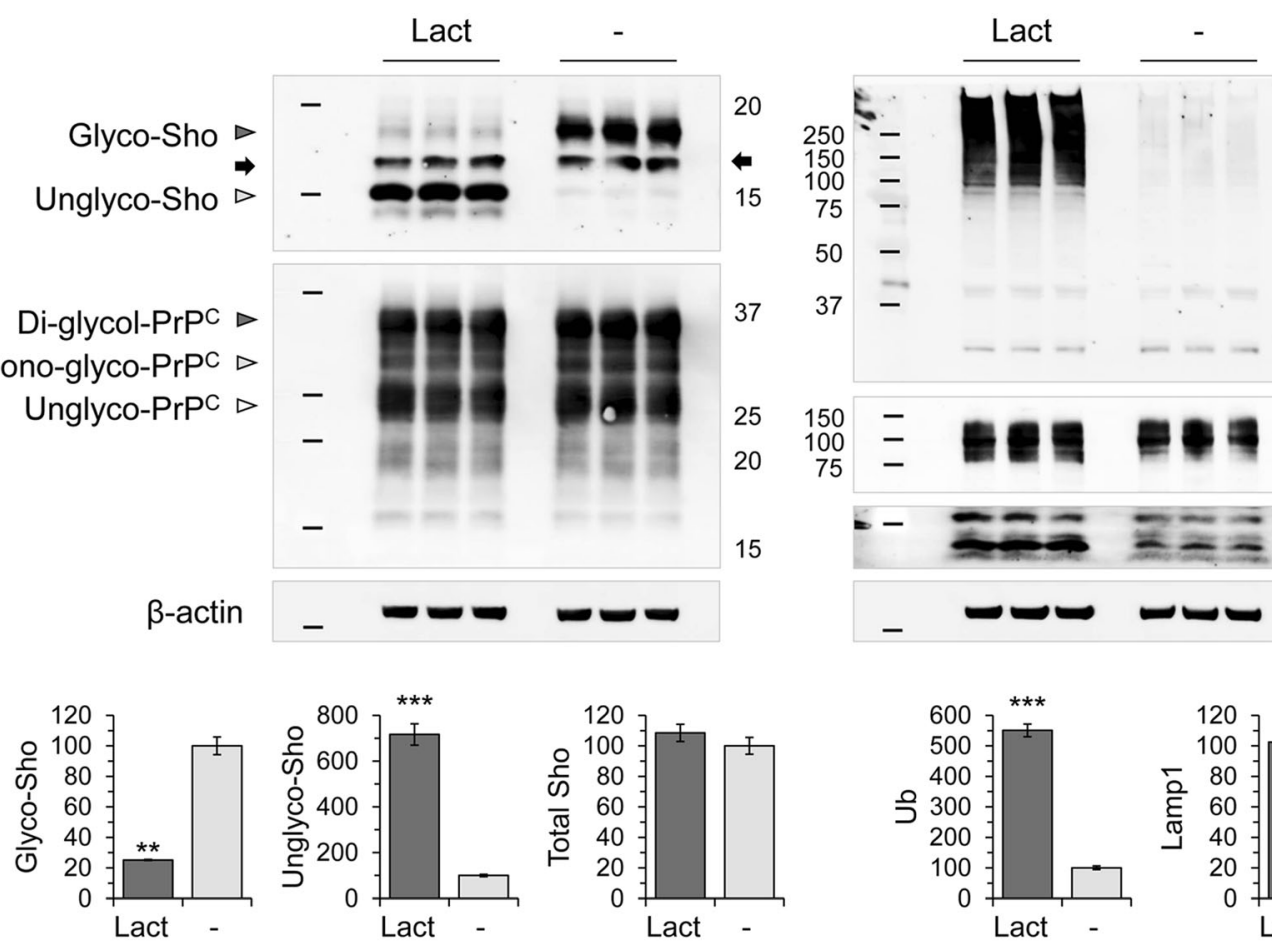

$\mathrm{Ub}$
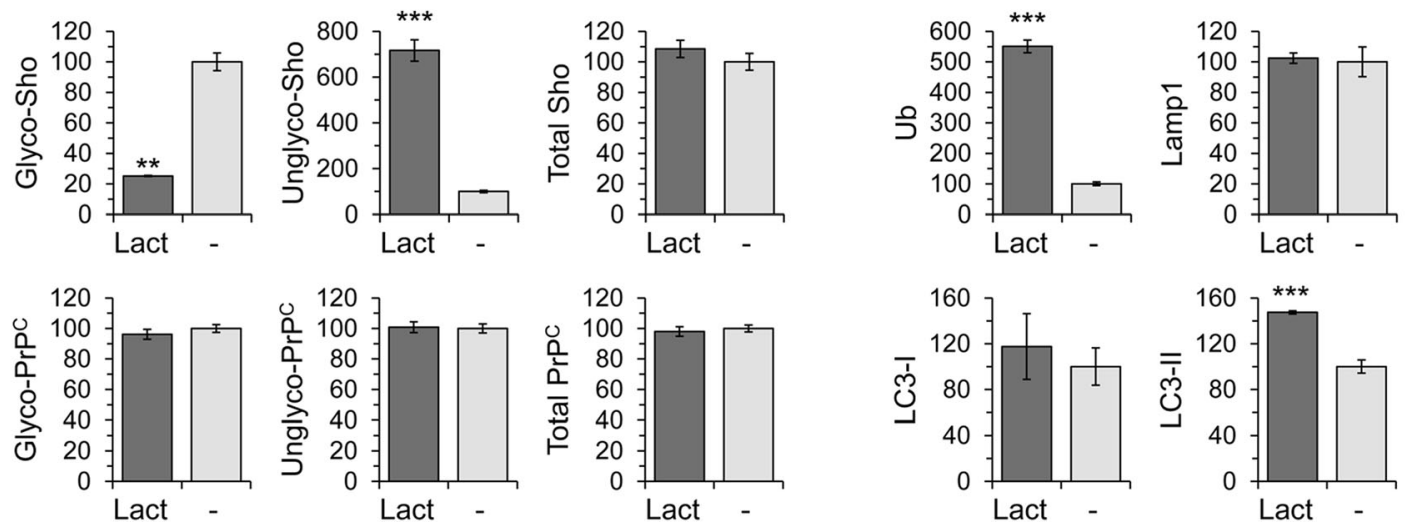

Fig. 1 Effect of lactacystin on Sho and $\operatorname{PrP}^{\mathrm{C}}$ expression in mouse MNGCs. a Domain structure of the Shadoo protein (Sho). Nterminal region to the hydrophobic domain (HD) includes tandem positively charged RGG boxes (25-61). A single N-linked glycosylation site is located in the $\mathrm{C}$-terminal region ( $\mathrm{CHO}$, residue 107) (top). Anti-Sho pAb, 06SH1 and 06SH3 have N-terminal epitope (30-60) and C-terminal epitope (86-100), respectively. In western blot analysis, Sho appears as a $22-\mathrm{kDa}$ glycosylated band (mature form), or 10-15-kDa unglycosylated bands depending on cleavage of the signal peptides (bottom). (i) unprocessed with both signal peptides intact; (ii) N-terminal signal peptide removed; (iii) both $\mathrm{N}$ - and C-terminal signal peptides removed. b Primary MNGCs were derived from Tg.Sprn mice and treated with lactacystin at $1 \mu \mathrm{M}$ concentration for $16 \mathrm{~h}(n=3)$. Expression of Sho, $\operatorname{PrP}^{\mathrm{C}}$, ubiquitin

(Ub), lysosome-associated membrane protein 1 (Lamp1), and microtubule-associated protein light chain 3 (LC3-I and LC3-II) was analyzed by western blot. A cross-reactive band is indicated with an arrow. Arrowheads indicate glycosylation of Sho (Glyco, glycosylated; Unglyco, unglycosylated) and $\mathrm{PrP}^{\mathrm{C}}$ (Di-glyco, diglycosylated; Mono-glyco, mono-glycosylated; Unglyco, unglycosylated). In the absence of PNGaseF treatment, $\operatorname{PrP}^{\mathrm{C}}$ fragments as well as full-length protein retain intact glycosylation sites, contributing to a complex electrophoretic profile). Molecular masses based on the migration of protein standards are shown in $\mathrm{kDa}$. c Intensity measurement of western blot results in $\mathbf{b}$. Intensities were normalized to those of $\beta$-actin loading controls. Error bars represent SD. $* * p<0.01$ and $* * * p<0.001$ in comparison with vehicle (water) treatment controls 
Proteasomal inhibition by a non-peptide inhibitor, lactacystin, increased polyubiquitinated protein levels $(550.8 \pm 20.8 \%)$ in Tg.Sprn-MNGCs compared with vehicle treatment controls (as 100\%). Protein levels of lysosome-

a

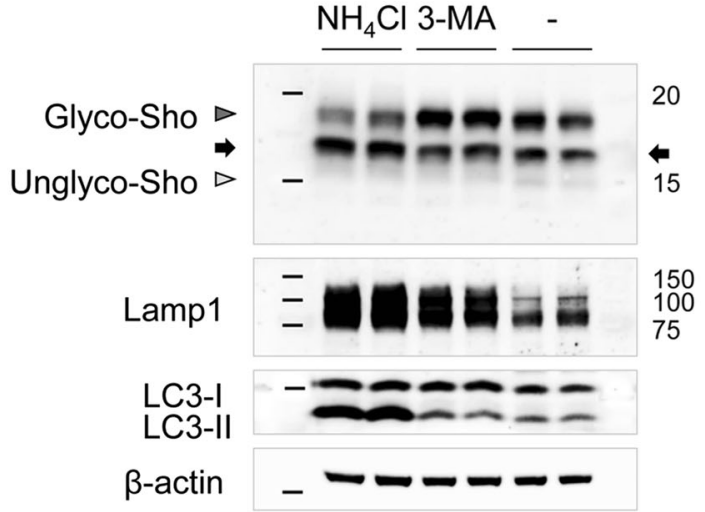

b

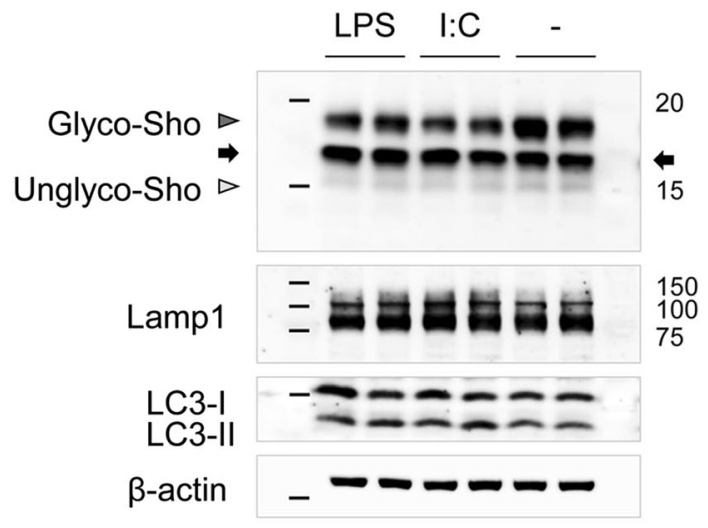

C

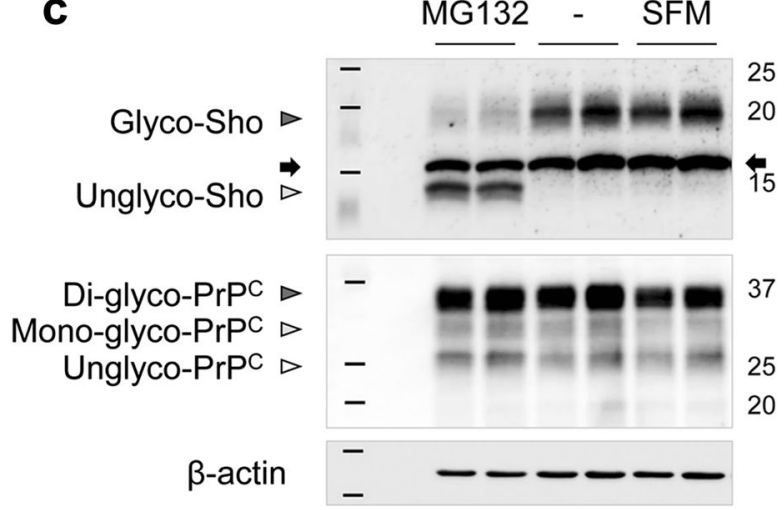

associated membrane protein 1 (Lamp1) and microtubuleassociated protein light chain 3 (LC3-I) were unaltered, while LC3-II increased (147.4 $\pm 1.4 \%)$, as previously reported [39, 40] (Fig. 1b, c). Lactacystin-mediated proteasomal inhibition
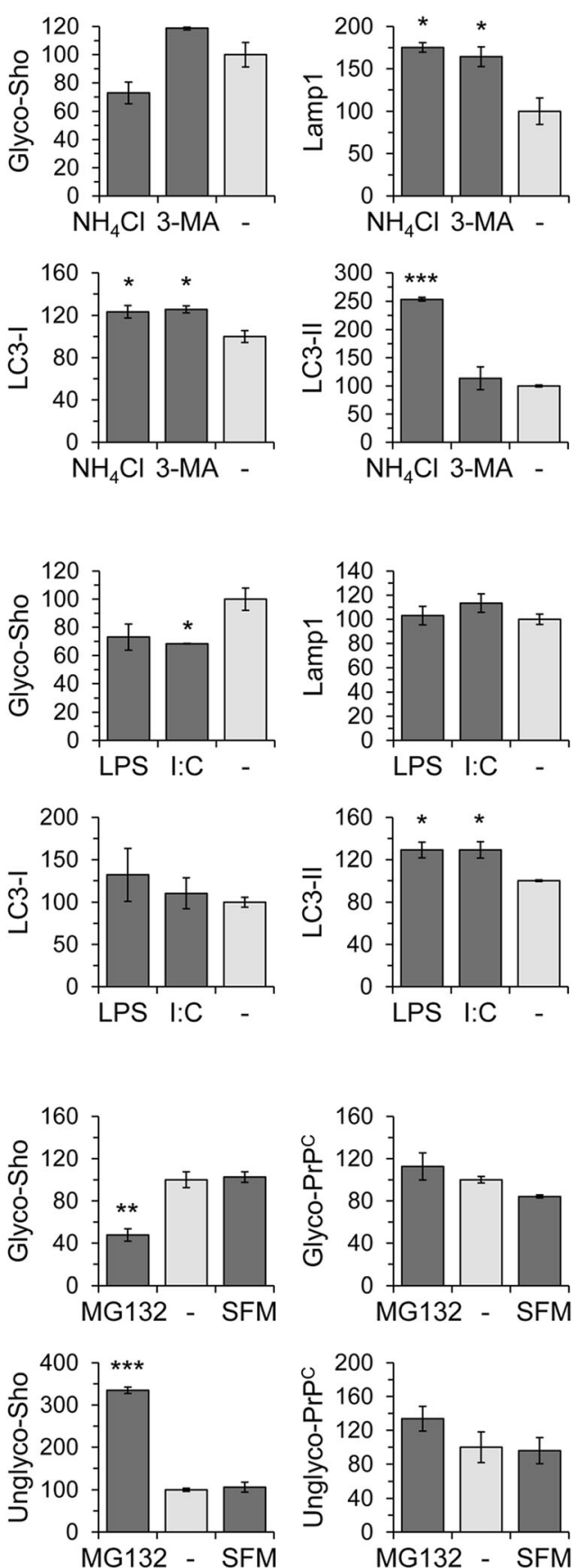

Fig. 2 Effects of autophagic modulators and innate immune ligands on Sho expression in MNGCs. Primary MNGCs were derived from Tg.Sprn mice and treated with a autophagic modulators $\left(\mathrm{NH}_{4} \mathrm{Cl}\right.$ or 3-MA at $10 \mathrm{mM}$ concentration) or $\mathbf{b}$ innate immune ligands (LPS or poly I:C at $10 \mu \mathrm{g} / \mathrm{mL}$ and $100 \mu \mathrm{g} / \mathrm{mL}$ concentration, respectively) for $16 \mathrm{~h}(n=2)$. Expression of Sho, lysosome-associated membrane protein 1 (Lamp1), and microtubule-associated protein light chain 3 (LC3-I and LC3-II) was analyzed by western blot. c To verify an alteration in glycosylation

profiles, which is mediated by MG132 (at $1 \mu \mathrm{M})$ rather than a transient stress condition, Tg.Sprn-MNGCs were maintained in serum-free medium $(\mathrm{SFM})$ for $16 \mathrm{~h}(n=2)$. Expression of Sho and $\operatorname{PrP}^{\mathrm{C}}$ was analyzed by western blot. A cross-reactive band is indicated with an arrow as per Fig. 1. Intensity measurements of western blot results are presented. Intensities were normalized to those of $\beta$-actin loading controls. Error bars represent SD. $* p<0.05, * * p<0.01$, and $* * * p<0.001$ in comparison with vehicle (water or dimethyl sulfoxide (DMSO)) treatment controls 
a

BH Tg.Sprn-MNGC's with MG132

BH Sprno/0-MNGC's with MG132

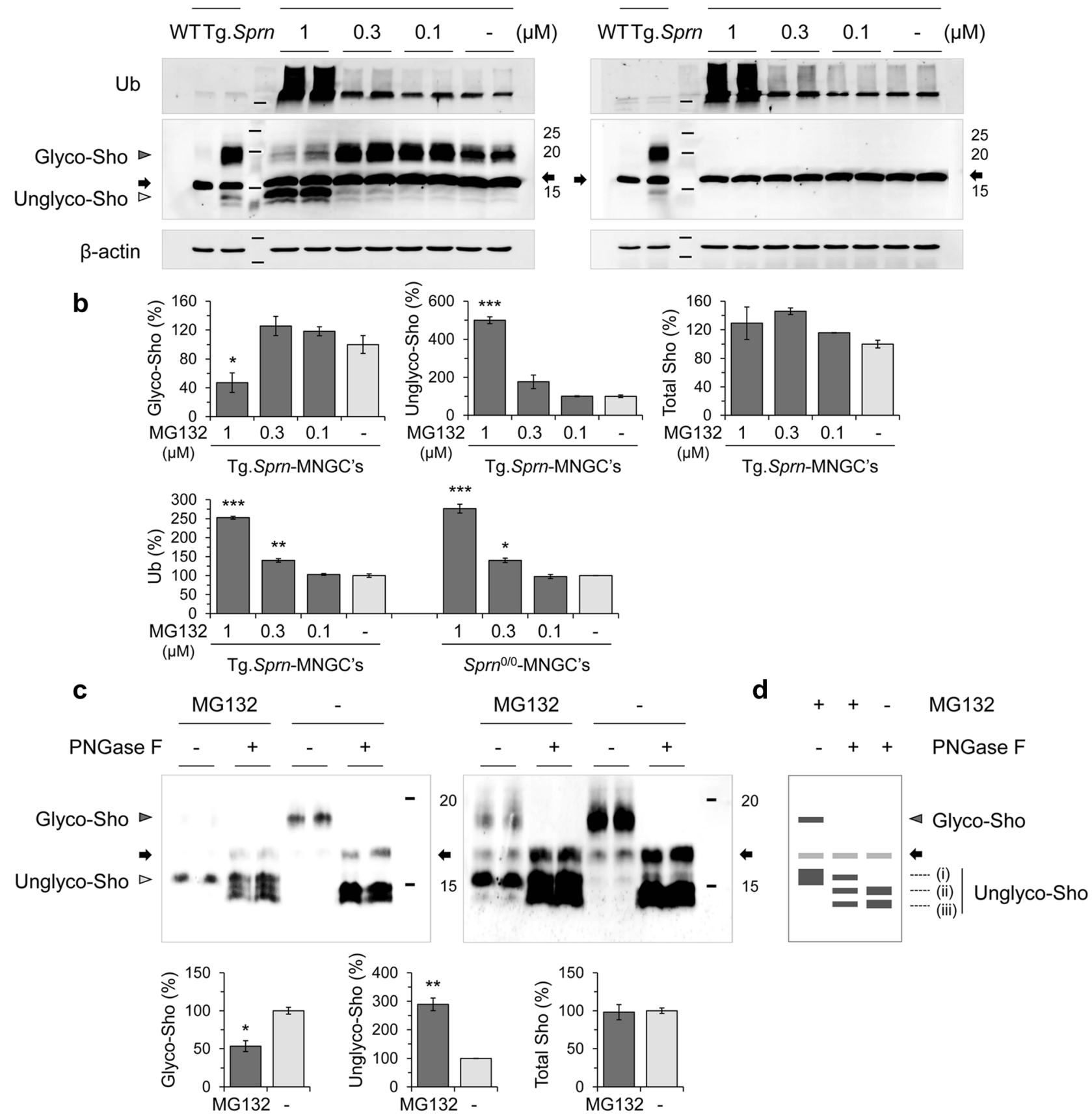

e

PNGase F

MG132

Di-glycol-PrPC $\triangleright$ Mono-glyco-PrPC $\triangleright$

Unglyco-PrPC $\triangleright$
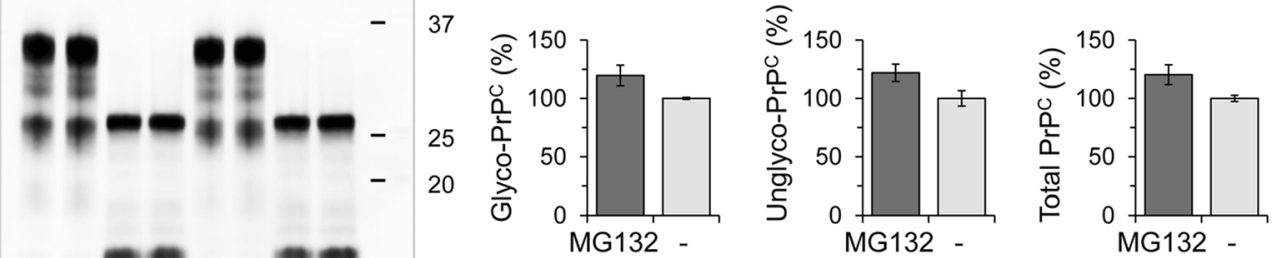

C1 $1 \quad \mathbf{m}=\mathbf{m}-15$$$
\text { ( }
$$ 
4 Fig. 3 Dose-dependent effect of MG132 on Sho and $\mathrm{PrP}^{\mathrm{C}}$ expression in MNGCs. a Primary MNGCs were derived from Tg.Sprn (left) and $\mathrm{Sprn}^{0 / 0}$ (right) mice, respectively. The cells were treated with MG132 at the indicated concentrations for $16 \mathrm{~h}(n=2)$. Expression of Sho and ubiquitin (Ub) was analyzed by western blot with designations of glycosylated species and a cross-reactive band as per Fig. 1. Brain homogenates of wild-type (BH-WT) and Tg.Sprn (BH-Tg.Sprn) mice were loaded as positive controls. b Intensity measurement of western blot results in a. Intensities were normalized to those of $\beta$-actin loading controls. c Primary MNGCs derived from Tg.Sprn mice were treated with MG132 $(1 \mu \mathrm{M})(n=2)$. The cell lysates $(10 \mu \mathrm{g})$ were incubated with PNGase F ( 25 units/sample) to digest $\mathrm{N}$-linked glycosylation and then expression of Sho was analyzed by western blot. The top and bottom panels are identical except for the exposure time; note extra band at $\sim 15-\mathrm{kDa}$ (threeband versus two-band signature for PNGase F-treated samples) with MG132 treatment. Intensity measurements of the Sho bands are presented. d Diagram representing the electrophoretic mobility of Sho species observed in western blot results (c) with designations of protein species as per Fig. 1a. e $\operatorname{PrP}^{\mathrm{C}}$ expression was analyzed in the same cell lysates tested in c. $\mathrm{C} 1$ designates a metabolically stable proteolytic product of $\mathrm{PrP}^{\mathrm{C}}$ processing. Intensities of the $\operatorname{PrP}^{\mathrm{C}}$ bands were measured. In the cell lysates without PNGase F, the relative amount of glycosylated proteins, including di-glycosylated and mono-glycosylated forms, and unglycosylated proteins is presented as a percentage to those of vehicle (DMSO) treatment controls. Error bars represent SD. $* p<0.05$, $* * p<0.01$, and $* * * p<0.001$ in comparison with the vehicle controls

decreased glycosylated forms of Sho $(25.1 \pm 0.4 \%)$ and increased unglycosylated forms $(716.4 \pm 46.9 \%)$, thereby not changing total levels of Sho, which were estimated as the sum of glycosylated and unglycosylated forms. $\operatorname{PrP}^{\mathrm{C}}$, although belonging to the same protein superfamily as Sho, did not demonstrate a change in glycosylation profile (Fig. $1 \mathrm{~b}, \mathrm{c})$. Autophagy-lysosome pathway modulations by $\mathrm{NH}_{4} \mathrm{Cl}$ and 3-MA significantly increased levels of Lamp1 $\left(175.3 \pm 5.7 \%\right.$ with $\mathrm{NH}_{4} \mathrm{Cl}$ and $164.4 \pm 11.7 \%$ with 3 -MA) and LC3-I $\left(123.5 \pm 6.0 \%\right.$ with $\mathrm{NH}_{4} \mathrm{Cl}$ and $125.8 \pm 3.4 \%$ with 3-MA). While lysosomal inhibition with $\mathrm{NH}_{4} \mathrm{Cl}$ caused an increased LC3-II levels $(253.5 \pm 2.9 \%)$ compared with vehicle (water) treatment. These treatments, however, did not significantly affect total levels and glycosylation profiles of Sho in Tg.Sprn-MNGCs (Fig. 2a). Proteasomal function can be compromised by the neuroinflammation which often accompanies neurodegeneration [32, 41-44], and as Sho has a nucleic acidbinding region [29] suggestive of a role in molecular pattern recognition after infections, we also tested the effects of two innate immune ligands. Although glycosylated Sho levels were mildly decreased by these treatments $(p=0.0295$ for poly I:C), unlike the effect of proteasomal inhibitors, we were unable to detect a commensurate increase in level for the unglycosylated forms of Sho (Fig. 2b). The proteasomal inhibition effect was further confirmed using a peptide aldehyde inhibitor, MG132. Like lactacystin, MG132 altered glycosylation of Sho (glycosylated Sho, $47.8 \pm 5.9 \%$; unglycosylated Sho, $334.7 \pm 7.5 \%$ ) without changing total Sho levels, while MNGCs maintained in serum-free medium (SFM)showed no alteration in glycosylation profile of both Sho and $\mathrm{PrP}^{\mathrm{C}}$ versus non-treated controls (Fig. 2c). These data indicate that proteasomal inhibition interfered with ER import of Sho and caused an abundance of unglycosylated Sho isoforms with a corresponding decrease in levels of glycosylated Sho.

The dose-dependent effects of MG132 on Sho expression were examined in Tg.Sprn-MNGCs and Sprn $^{0 / 0}$-MNGCs (which serve as a negative control culture). MG132 at $1 \mu \mathrm{M}$ concentration increased polyubiquitinated protein levels in the both cultures, regardless of Sho transgene $(252.6 \pm 3.6 \%$ in Tg.Sprn-MNGCs and $276.4 \pm 11.6 \%$ in Sprn $^{0 / 0}{ }^{-M N G C s)}$ (Fig. 3a, b). MG132-mediated proteasomal inhibition decreased glycosylated forms of Sho $(47.2 \pm 13.6 \%)$, whereas unglycosylated forms of Sho were increased (499.5 \pm $18.1 \%)$ compared with vehicle treatment controls. The total Sho level including both glycosylated and unglycosylated forms was however unchanged (Fig. 3a, b). The increase in putatively unglycosylated forms implies an impaired Sho import into the ER. Nascent proteins destined to become GPIlinked have $\mathrm{N}$ - and $\mathrm{C}$-terminal signal peptides cleaved off as they are processed through the secretory pathway (see Fig. 1a). To check the presence of processed forms of Sho in Tg.Sprn-MNGCs with MG132, we removed N-linked sugars with PNGase $\mathrm{F}$ to obviate confounding effects of sugar chains on electrophoretic mobility (Fig. 3c, d). In control cells with no MG132, two bands denoted as (ii) and (iii) as per Fig. 1a were observed after PNGase F treatment. Band (iii) corresponds to fully processed Sho while band (ii) is inferred to represent retention of the $\mathrm{C}$-terminal signal peptide. PNGase F-treated samples from cells cultured with MG132 had an additional species, (i), inferred to represent retention of both signal peptides. This $\sim 15-\mathrm{kDa}$ species migrated in a similar but non-identical fashion to the species seen in MG132treated cell lysates without PNGase F digestion (Fig. 3c, d) and it also had a similar signal intensity. These data suggest that the predominant form of Sho under conditions of proteasomal inhibition is unglycosylated and contains uncleaved $\mathrm{N}$ - and $\mathrm{C}$-terminal signal peptides. In parallel experiments, glycosylation of $\operatorname{PrP}^{\mathrm{C}}$ was not affected by the same MG132 treatment (Fig. 3e), indicating no effect of this drug on ER maturation.

\section{Nuclear Localization of Sho in MNGCs}

MNGCs derived from Tg.Sprn mice were treated with MG132 and fixed for immunocytochemical analysis. As per earlier studies, intracellular signals were seen for wild-type Sho [11] and were observed in some microtubule-associated protein 2 (MAP2)-positive neurons with no treatment (vehicle controls), while other neurons had weak nuclear staining (Fig. 4a); it is fully possible that these nuclear signals represent cross-reactivity with an antigen other than Sho. In contrast, however, MG132 treatment $(1 \mu \mathrm{M})$ increased the strength and uniformity of nuclear Sho signals in MAP2-positive neurons 


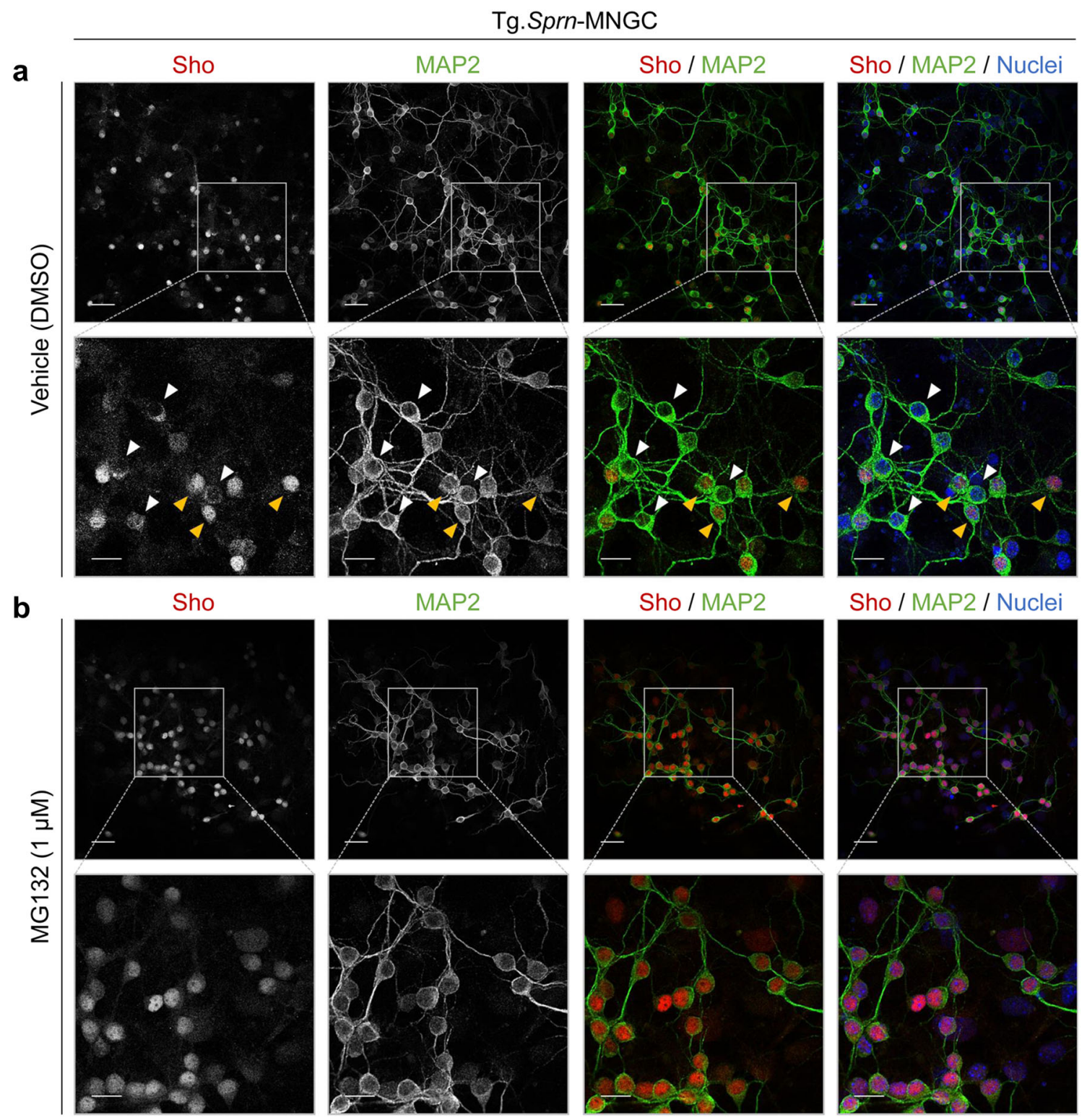

Fig. 4 Nuclear localization of Sho in MNGCs with MG132 treatment. Primary MNGCs were derived from Tg.Sprn mice at postnatal day 7, then cultured for 7 days with the last $16 \mathrm{~h}$ of growth in the presence of MG132 $(1 \mu \mathrm{M})$. The cells were then fixed and permeabilized. Sho (06SH1) and microtubule-associated protein 2 (MAP2) were probed with fluorescentconjugated secondary antibodies. Sho in red; MAP2 in green. Nuclei were counterstained with Hoechst 33342 dye (blue). a Vehicle (DMSO) treatment controls showed intracellular localization of Sho signals (white arrowheads) with occasional diffuse nuclear staining in other cells (yellow arrowheads). b MG132 treatment triggered an increased nuclear localization of Sho. Scale bar, $20 \mu \mathrm{m}$ and $10 \mu \mathrm{m}$ in the boxed images

$10 \mathrm{kDa}$ in size were also detected in the MG132- and lactacystin-treated nuclear fractions of primary granule neurons and glial cultures (Fig. 5a).

\section{Proteasomal Inhibition and Sho Expression in N2a-Sprn}

The effect of proteasomal inhibition on Sho expression was present in N2a murine neuroblastoma cells expressing Sho under control of human elongation factor 1 alpha (EF$1 \alpha)$ promoter $(\mathrm{N} 2 \mathrm{a}-S p r n)$. N2a-Sprn cells were treated

(Fig. 5a, b). Interestingly, cleaved Sho bands smaller than 


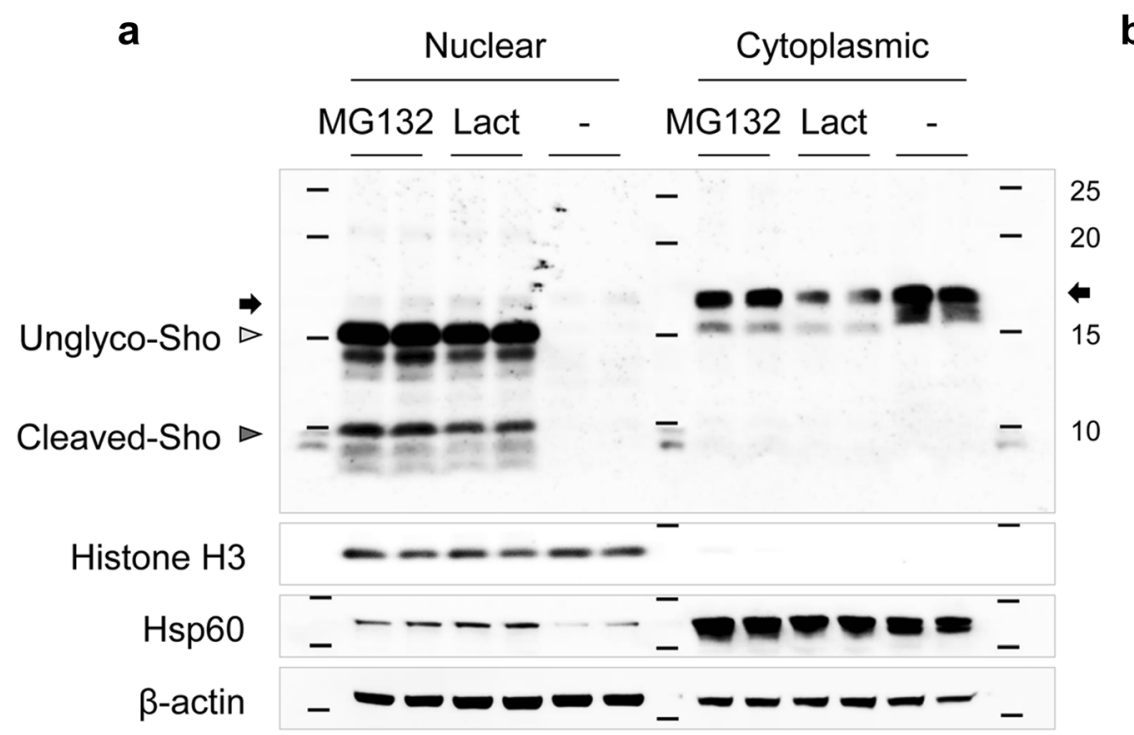

b
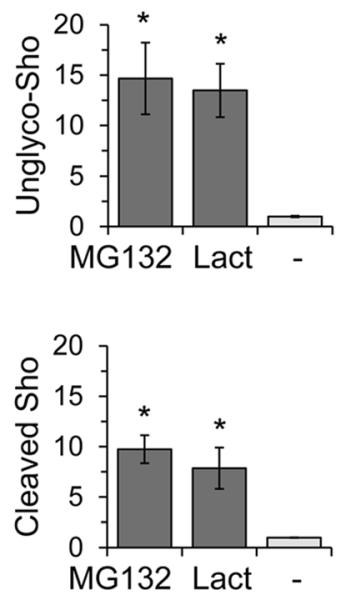

Fig. 5 Subcellular fractionation of MNGCs treated with MG132 and lactacystin. a Tg.Sprn-MNGCs were treated with MG132 $(1 \mu \mathrm{M})$ or lactacystin (Lact, $1 \mu \mathrm{M})$ for $16 \mathrm{~h}$ and harvested after trypsinization $(n=$ 2). Nuclear and cytoplasmic extracts were prepared by differential detergent fractionation. Nuclear localization of Sho under proteasomal inhibition conditions was analyzed by western blot of the subcellular fractions. Histone H3, a nuclear marker; Hsp60, heat shock protein 60, a mitochondrial marker; $\beta$-actin, a loading control. Note strong accumulation of a $15-\mathrm{kDa}$ species (migrating faster than the cross-reactive band) putatively

with the proteostatic modulators, including MG132, $\mathrm{NH}_{4} \mathrm{Cl}$, and 3-MA, and expression of Sho species was again determined by western blot analysis. Like in Tg.Sprn-MNGCs, MG132 (1 $\mu \mathrm{M})$ increased polyubiquitinated protein levels and caused glycosylation variation with a predominance of unglycosylated Sho over glycosylated forms (Fig. 6a). Investigation of the dosedependent effect of MG132 in N2a-Sprn revealed that unglycosylated Sho increased with MG132, while glycosylated Sho showed an inverse relationship with increasing amounts of MG132 (Fig. 6b, c). Unglycosylated $\mathrm{PrP}^{\mathrm{C}}$ increased with MG132 in a manner somewhat similar to Sho; however, glycosylated forms were little affected by the treatment doses (Fig. 6c).

\section{Nuclear Localization of Sho in N2a-Sprn}

The inferred impaired import of Sho into ER under proteasomal inhibition conditions was correlated with notable nuclear translocation of Sho in N2a-Sprn cells, similar to that observed in the primary Tg.Sprn-MNGCs. The N2a-Sprn cells were treated with MG132 and fixed for immunocytochemistry. Sho signals were detected evenly through the cell body under normal culture condition (vehicle controls), whereas nuclear Sho signals were increased by MG132 treatment (Fig. 7a, b). Unlike the situation with Sho translocation, intracellular and cell surface signals of endogenous $\operatorname{PrP}^{\mathrm{C}}$ were representing full-length unglycosylated Sho retaining both signal peptides. Signals indicative of candidate cleavage products were also prominently represented (versus being undetectable in matching cytoplasmic fractions). b Intensity measurement of nuclear Sho in western blot results (a). Intensities were normalized to those of histone H3. Error bars represent SD. ${ }^{*} p<0.05$ in comparison with vehicle (DMSO) treatment controls. Designations of glycosylated species and a cross-reactive band are as per Fig. 1

evident in N2a-Sprn, regardless of MG132 treatment (Fig. 8a, b). To further verify the nuclear localization of Sho, the nuclear and cytoplasmic fractions of N2a-Sprn treated with MG132 or lactacystin were analyzed by western blot. Similar to Tg.Sprn-MNGCs (Fig. 5a), glycosylated forms were barely detectable, presumably due to a trypsinization step performed before cell harvesting. The $\sim 15-\mathrm{kDa}$ bands, corresponding to the unglycosylated Sho, were detected in the nuclear fractions with both MG132 and lactacystin treatments (Fig. 9a, b). These data indicate that, under condition of proteasomal inhibition, Sho translocates into the nucleus, instead of undergoing post-translational maturation through the secretory pathway.

\section{Discussion}

Earlier work has indicated that general proteostatic pathways may be engaged in response to prion infections of the CNS tissue. Some of these data correspond to decreases in the steady-state levels of Sho and the cellular isoform of prion protein $\left(\operatorname{PrP}^{C}\right)$ [11, 17-20, 45], while others have studied interactions of infectivity-associated isoforms of prion protein $\left(\mathrm{PrP}^{\mathrm{Sc}}\right)$ with the proteasome [46, 47] or performed genomewide analyses to implicate the ubiquitin ligase Hect2D [48]. $\mathrm{PrP}^{\mathrm{Sc}}$ levels in both central and peripheral neuronal cells were reduced by intracellular proteolytic activities; thus, autophagy 
a

Ub
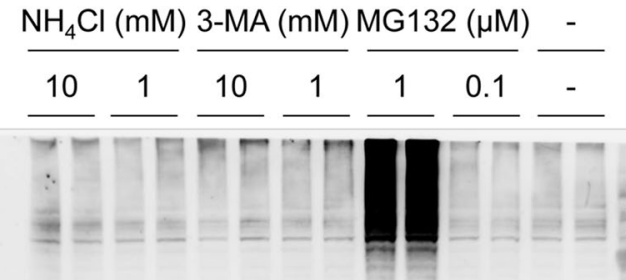

$-\infty-\infty-\infty \cdots-\infty$

Glyco-Sho $\triangleright$

Unglyco-Sho $\vec{D}$

Di-glyco-PrPC $\triangleright$ Mono-glyco-PrPC $\triangleright$

Unglyco-PrPC $\triangleright$

$\beta$-actin

C
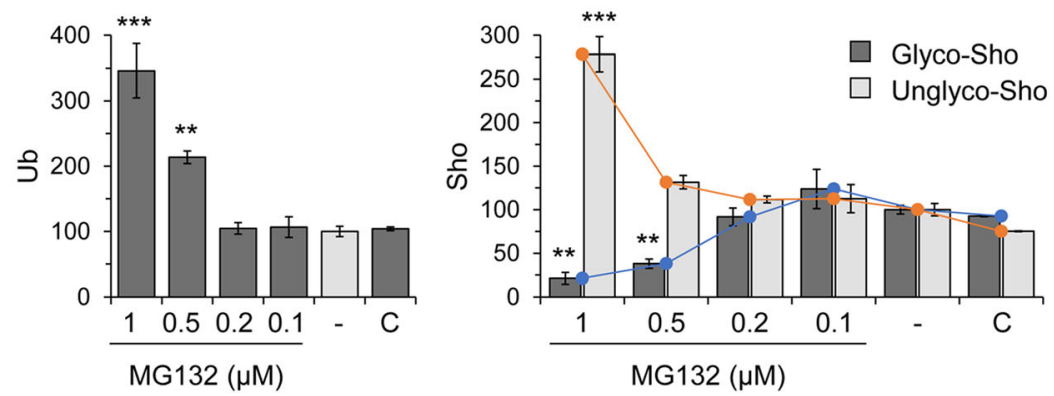

b
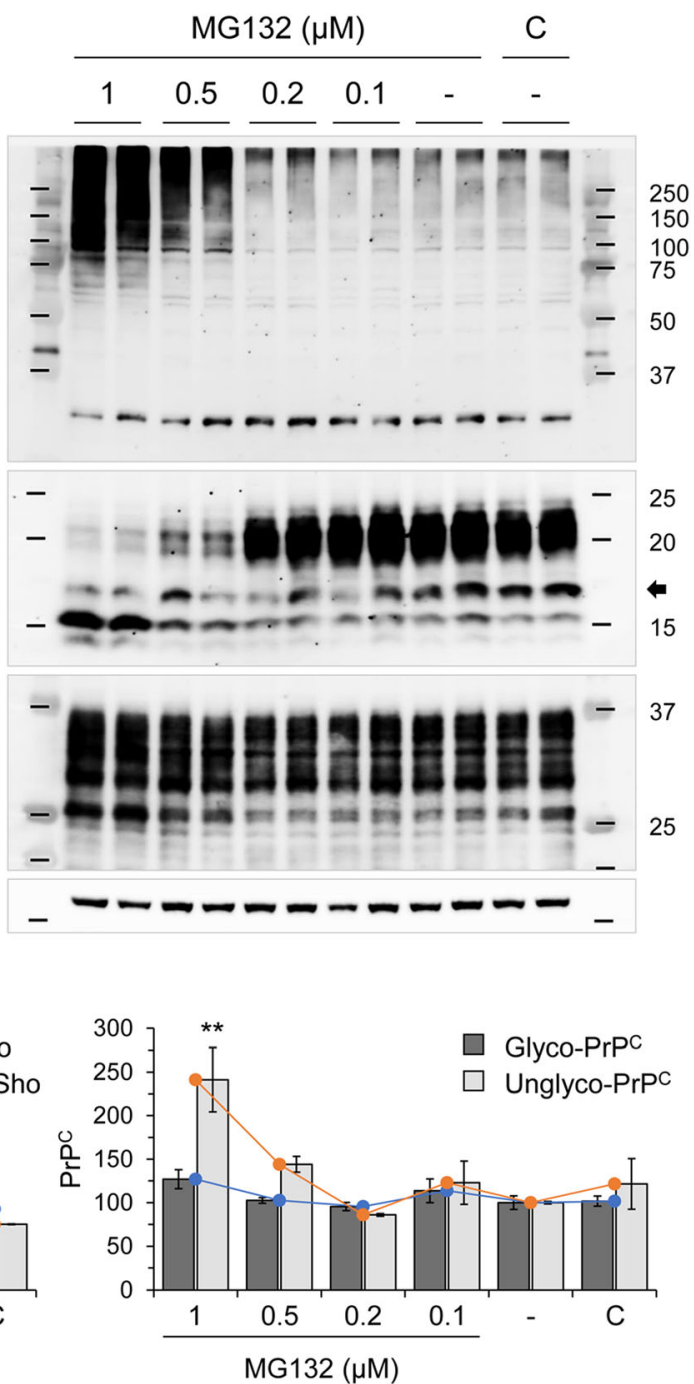

Fig. 6 Selective effects of proteostatic modulators on Sho expression in N2a-Sprn. a N2a-Sprn cells were treated with the modulators targeting proteolytic system including $\mathrm{MG} 132, \mathrm{NH}_{4} \mathrm{Cl}$, and 3-MA at the indicated concentrations for $16 \mathrm{~h}(n=2)$. Expression of Sho, $\operatorname{PrP}^{\mathrm{C}}$, and ubiquitin (Ub) was analyzed by western blot, revealing the effect of MG132 treatment versus lack of effects for $\mathrm{NH}_{4} \mathrm{Cl}$ and 3-MA. b Dose-dependent effect of MG132 on Sho and $\mathrm{PrP}^{\mathrm{C}}$ expression in N2a-Sprn. The cells were treated with MG132 at the indicated concentrations for $16 \mathrm{~h}(n=$
2). Expression of Sho, $\operatorname{PrP}^{\mathrm{C}}$, and $\mathrm{Ub}$ was analyzed by western blot. $\mathrm{C}$ designates a normal culture condition (with no MG132 and no vehicle) while designations of glycosylated species and a cross-reactive band are as per Fig. 1. c Intensity measurement of western blot results in b. Intensities were normalized to those of $\beta$-actin loading controls. Error bars represent SD. $* * p<0.01$ and $* * * p<0.001$ in comparison with vehicle (DMSO) treatment controls

housekeeping gene $(\mathrm{EF}-1 \alpha)$ promoter to direct expression of mRNAs encoding untagged wild-type mouse Sho. With these experimental parameters and within different cellular systems, we found that inhibition of the proteasome (with either lactacystin or MG132) invokes a repartitioning effect, rather than a change in the net levels of all Sho species. This effect involves an altered targeting decision for Sho, leading to more substantial levels in the nucleus (summarized in Fig. 10). This stands in contrast to the proposition that glycosylation is a causal determinant of changes in Sho populations [21].

Related to the configuration of experimental paradigms, we also observed massive increases in the levels of all forms of Sho (i.e., glycosylated, unglycosylated, and low molecular weight (versus 1.0 expression in wild-type mice [19]) and (b) a 
Fig. 7 Nuclear localization of Sho in N2a-Sprn with MG132 treatment. N2a-Sprn cells were treated with MG132 $(1 \mu \mathrm{M})$ for $16 \mathrm{~h}$. The cells were then fixed and permeabilized. Sho was probed anti-Sho $\mathrm{pAb}, 06 \mathrm{SH} 3$. a Vehicle (DMSO) treatment controls showed a uniform distribution of Sho signals through the cell body. b MG132 treatment triggered a nuclear localization of Sho (white arrowheads). Sho in green. Nuclei were counterstained with Hoechst 33342 dye (blue).

Scale bar, $20 \mu \mathrm{m}$ and $10 \mu \mathrm{m}$ in the boxed images

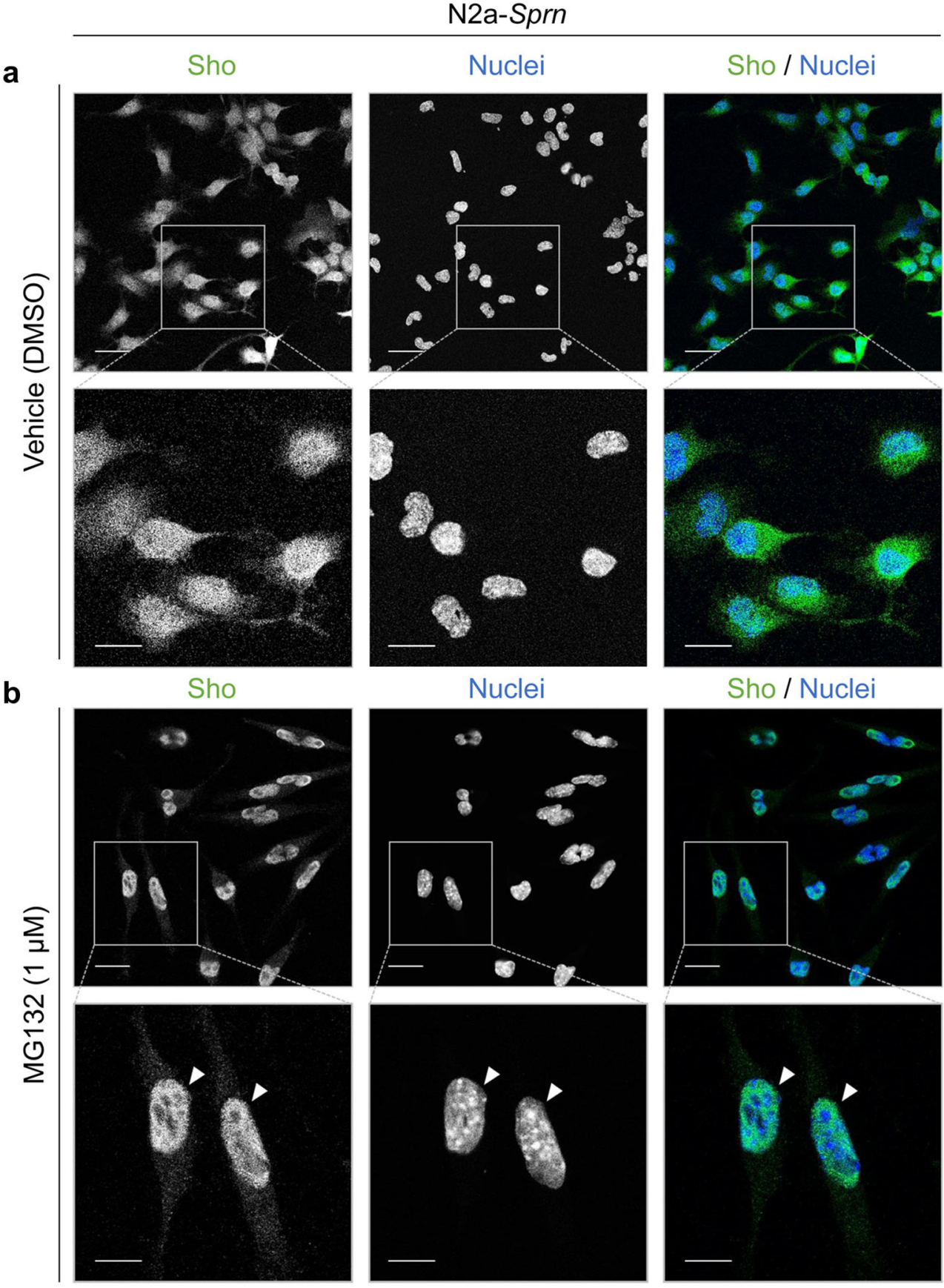

fragments) in the presence of 3-MA or MG132 when using a human cytomegalovirus (CMV) promoter in uninfected $\mathrm{N} 2 \mathrm{a}$ cells or in chronically infected $\mathrm{N} 2 \mathrm{a}$ cells (ScN2a) (Fig. S1). Superficially, these data suggest profound regulation of Sho under basal conditions by both proteasomal and autophagic pathways but these data also overlap a prior finding where increases in $\operatorname{PrP}^{\mathrm{C}}$ levels were achieved by treatments with proteasomal inhibitors when the protein is expressed from the CMV promoter [52]. In line with this work from other labs, the robust across-the- board effect obtained for Sho using CMV promoters was considered an artifact and not pursued further.

Results presented here echo the general concept that Sho has flexibility in terms of its cellular destination [16, 26, 45], sometimes referred to as "dual targeting." But, rather than having a constitutively leaky signal peptide that leads to cytoplasmic delivery as per the literature for $\mathrm{PrP}^{\mathrm{C}}$ [22-25], a reduction of Sho expression at the cell surface and an increase of expression in the nucleus were 
Fig. 8 Cell surface and intracellular expression of $\operatorname{PrP}^{\mathrm{C}}$ in N2a-Sprn. N2a-Sprn cells were treated with MG132. The cells were then fixed and permeabilized. $\operatorname{PrP}^{\mathrm{C}}$ was probed with anti-PrP mAb, SAF83. Immunocytochemistry revealed cell surface and intracellular expression of endogenous $\operatorname{PrP}^{\mathrm{C}}$ in N2a-Sprn, regardless of MG132 treatment. a Vehicle (DMSO) treatment control cells; $\mathbf{b}$ cells treated with MG132 treatment at $1 \mu \mathrm{M} . \operatorname{PrP}^{\mathrm{C}}$ in green. Nuclei were counterstained with Hoechst 33342 dye (blue). Scale bar, $20 \mu \mathrm{m}$ and $10 \mu \mathrm{m}$ in the boxed images

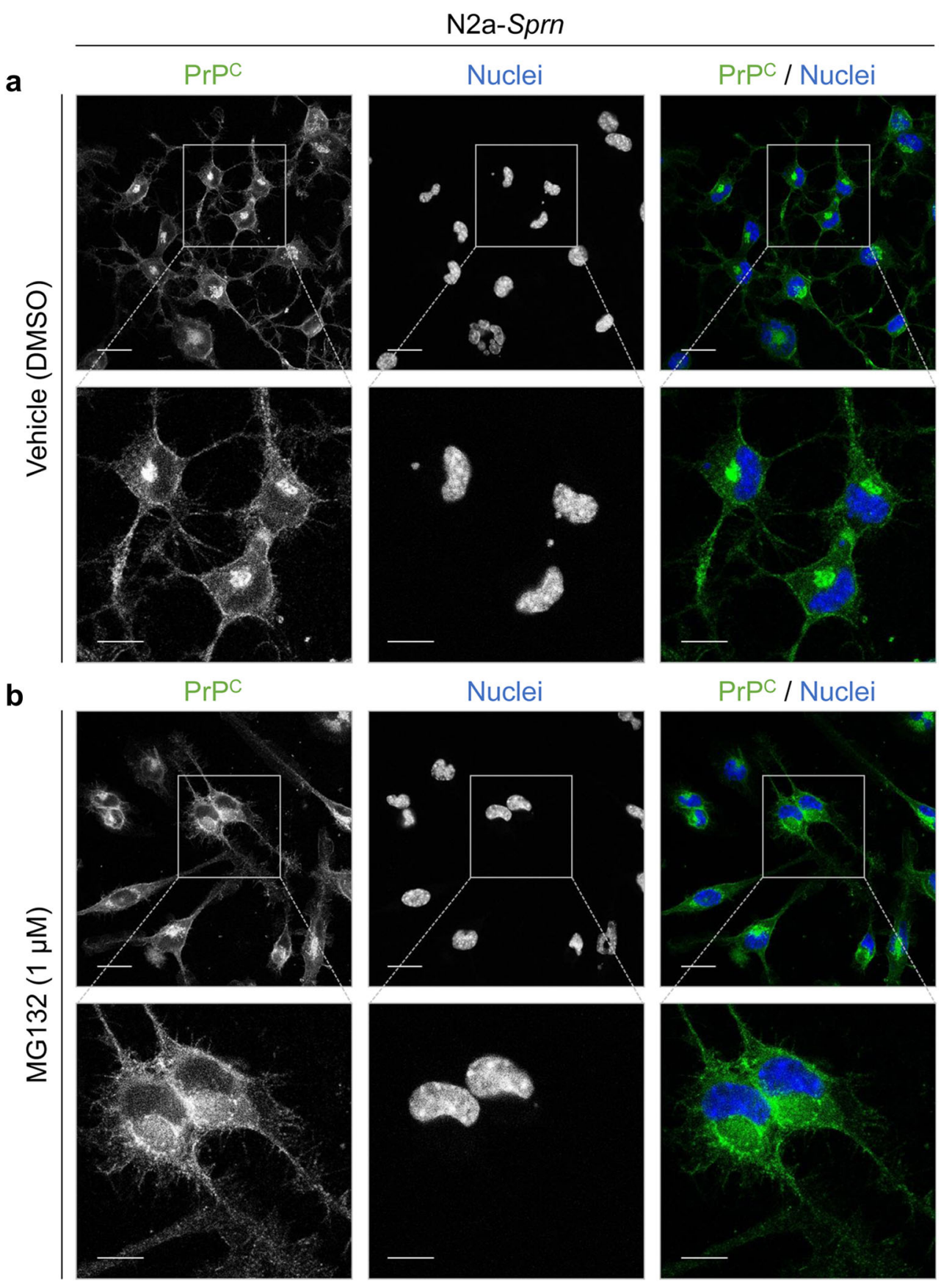

noted following proteasomal inhibition. Also, the details of our findings diverge from some other studies. While repartitioning of Sho to mitochondria is reported for conditions which reduce ER import (as produced by drugs or siRNAs that target the Sec61-containing translocon complex) [26], movement to this destination was not a prominent effect in our studies; cross-contamination of mitochondria into nuclear or cytoplasmic subcellular fractions was assessed by use of anti-heat shock protein 60 (Hsp60) antibody with a presence in cytoplasmic fractions being more notable (Figs. 5a and 9b). However, it remains possible that a subset of Sho lies within mitochondria below our level of detection.

In terms of mechanism, our data do not point to a relocalization whereby mature Sho at the cell surface is redirected internally for nuclear importation. This type of effect involving glycosylated molecules would likely contravene rules for such importation [53, 54]. Instead, we infer repartitioning as a result of nascent protein molecules on ribosomes engaging/not engaging the ER translocon 

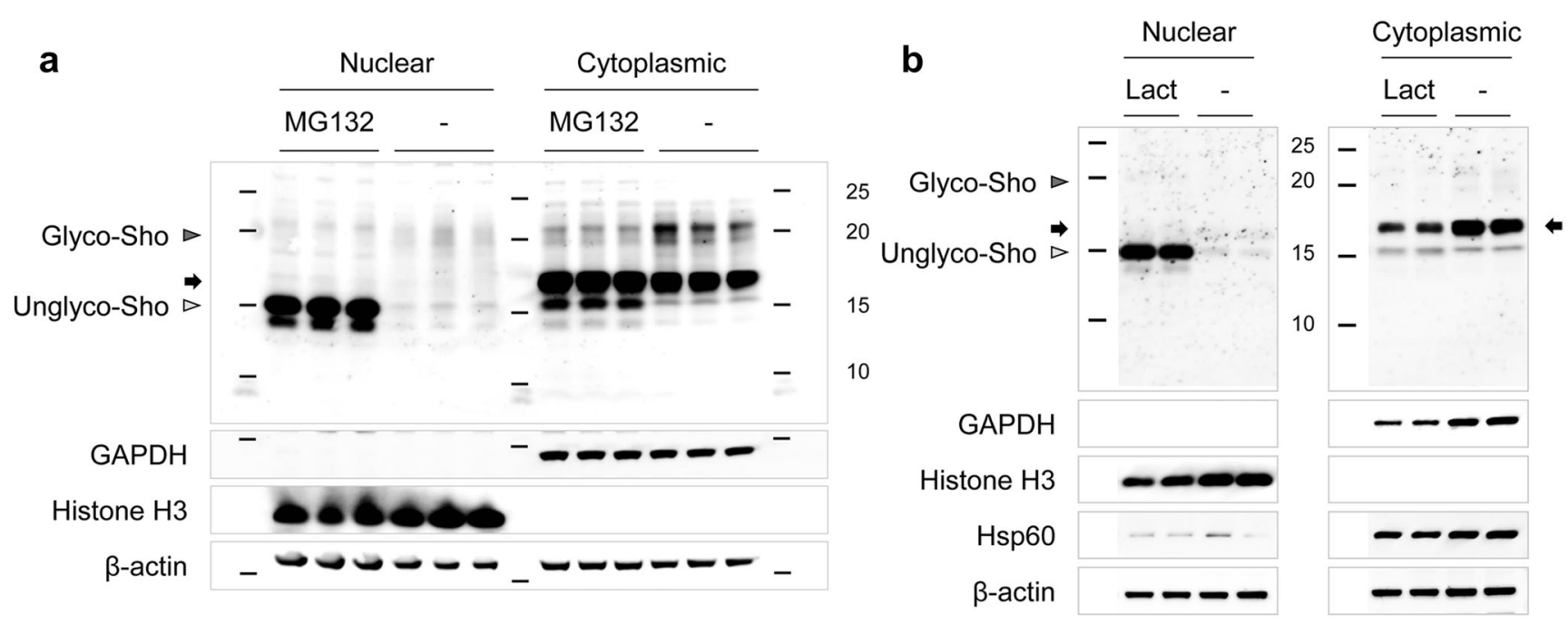
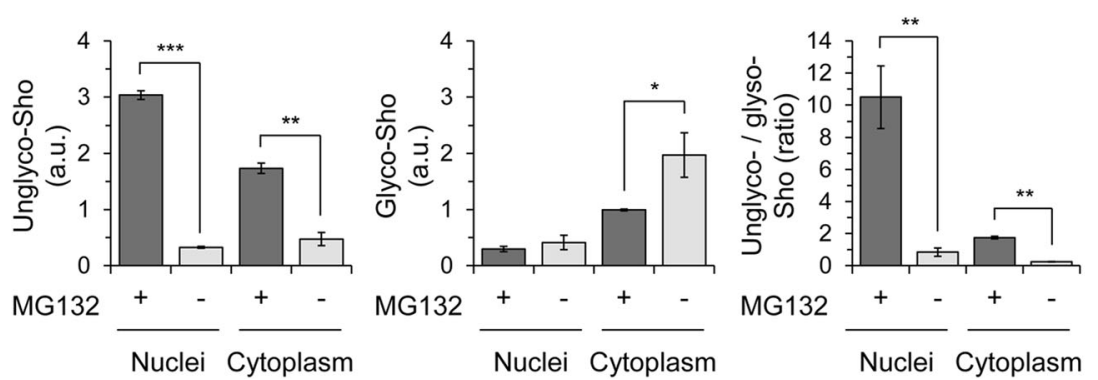

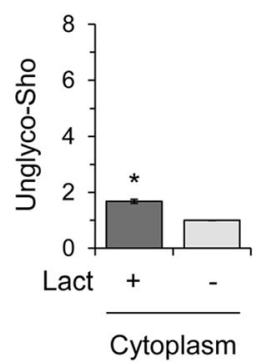

Fig. 9 Subcellular fractionation of N2a-Sprn treated with MG132 and lactacystin. N2a-Sprn cells were treated with a MG132 $(1 \mu \mathrm{M})$ or b lactacystin (Lact, $1 \mu \mathrm{M})$ for $16 \mathrm{~h}$ and harvested after trypsinization $(n=$ 3 for MG132, $n=2$ for Lact). Nuclear and cytoplasmic extracts were prepared by differential detergent fractionation. Nuclear localization of Sho under proteasomal inhibition conditions was analyzed by western blot of the subcellular fractions. Note prominent $15-\mathrm{kDa}$ signal migrating beneath the position of the cross-reactive species. GAPDH,

glyceraldehyde 3-phosphate dehydrogenase, a cytoplasmic marker; Histone $\mathrm{H} 3$, a nuclear marker; Hsp60, heat shock protein 60, a mitochondrial marker; $\beta$-actin, a loading control. Intensity measurement of western blot results was presented. Intensities were normalized to those of histone H3 (nuclear extracts) or GAPDH (cytoplasmic extracts). Error bars represent SD. $* p<0.05, * * p<0.01$, and $* * * p<0.001$ in comparison with vehicle (DMSO) treatment controls. Designations of glycosylated species and a cross-reactive band are as per Fig. 1

machinery (an idea partly related to other studies that emphasize mitochondrial import $[16,26])$. For Sho synthesized on cytoplasmic ribosomes, excision of N- and Cterminal signal peptides will not occur because the relevant endopeptidases are expressed in the secretory pathway. Indeed, the predominant form of Sho detected in MG132treated cells has a gel mobility slower than two forms of in vitro deglycosylated Sho from untreated cells, indicating that both signal peptides are retained (Fig. 3c, d). This finding is perhaps in accordance with the reciprocal idea that absence of the GPI signal sequence is required for the mitochondrial importation of Sho [26]. Analyses of control cells lacking MG132 treatment demonstrated two approximately equimolar species after PNGase F treatment ("ii" and "iii" in Fig. 3c and d); while the faster-migrating species must correspond to removal of the C-terminal GPI signal peptide, the slower-migrating signal could reflect retention of this signal peptide and hence an inefficiency in processing in MNGCs. Interestingly, cleaved fragments of Sho were observed in neuronal and glial mixed cultures (Tg.Sprn-MNGCs) with MG132 or lactacystin treatment (Fig. 5a), but not in N2a-Sprn cells (Fig. 9a, b). This data may indicate that, as one of the most active roles of glial cells in the nervous system is phagocytic clearance, glial cells including astrocytes and microglia in MNGCs take up material from granule neurons under conditions of proteasomal inhibition, unlike the situation in the N2a cell monocultures. Examining the glycosylation status of the immunoreactive material in glia and the presence of N1/ $\mathrm{C} 1$ or $\mathrm{N} 2 / \mathrm{C} 2$ fragmentation [55] may be instructive in determining its mechanistic origin from the cytoplasmic or secretory pathway of neurons.

Sho's N-terminal half is arginine-rich and includes RGG motifs (and degenerate versions thereof) that are predicted to mediate binding to DNA or RNA [28] and work on recombinant Sho fragments revealed that this 
Fig. 10 Graphic summary of proteasomal inhibition-induced nuclear localization of Sho. a Sho, a highly conserved member of prion protein family, and $\operatorname{PrP}^{\mathrm{C}}$ are imported into the ER and posttranslationally modified with $\mathrm{N}$ linked glycans. The matured glycoproteins are targeted to the lipid rafts of plasma membrane via GPI anchor. Unprocessed or misfolded proteins are eliminated through ER-associated degradation (ERAD) as an ER quality control (ERQC) system. b An interference of the ubiquitin-proteasome system (UPS) with proteasome inhibitors, MG132 and lactacystin (Lact), causes an impaired ER import of Sho, however not $\operatorname{PrP}^{\mathrm{C}}$. Instead of a canonical modification through ER, Sho is localized to the nucleus. Proteins and sugars are indicated by oval and square shapes, respectively
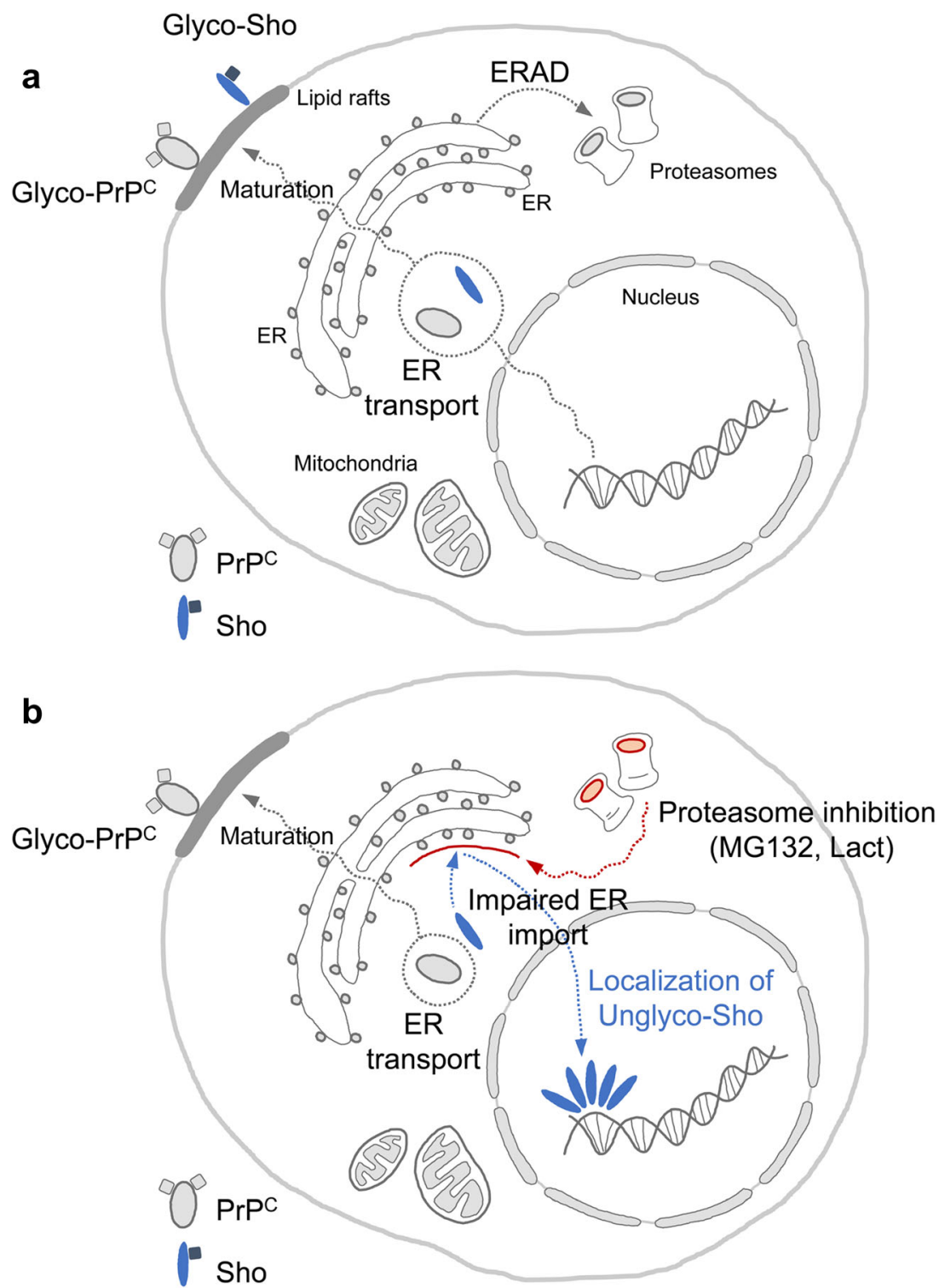

effect does manifest in vitro [29]. While cell surface fulllength Sho can be considered as a potential pattern recognition receptor [56] that could bind to extrinsic RNAs, we found that innate immune ligands had negligible effects upon Sho levels or glycosylation profile (Fig. 2b). On the other hand, when Sho is synthesized from cytoplasmic ribosomes, a latent capacity for nucleic acid binding might come to the fore. In studies using Sho-YFP fusion proteins under resting cell conditions, nuclear location and a nuclear localization signal (NLS) were inferred for Sho [27]. Though these observations align, the biological properties of Sho species when they reach the nucleus are, as yet, unclear. There is now much interest in the low complexity domains of RNA binding proteins and their ability to undergo phase transitions when they aggregate, making transient organelles that are not delimited by lipid bilayers. Since recombinant Sho is natively disordered $[11,14,26,27]$ and has low sequence complexity (Arg, Gly, Ala, and Val residues account for $90 \%$ of residues in mouse Sho 25-87), probing for these types of structural transitions might provide a firmer grip on function [57].

In spite of $\operatorname{PrP}^{\mathrm{C}}$ having its own literature on nucleic acid binding and two putative NLS sequences [58-61], when we examined endogenous $\operatorname{PrP}^{\mathrm{C}}$ molecules in our experimental paradigms, we did not detect a propensity to alter location or to manifest with different glycotypes (the latter in accord with a prior literature $[62,63]$ ). A simple way to view these findings is in terms of a predominating role for RGG motifs in specifying nucleic acid binding and nuclear localization [27, 29] and the 
presence (Sho) or absence $\left(\operatorname{PrP}^{\mathrm{C}}\right)$ of these motifs prior to the central hydrophobic region of the respective proteins. Also, with full-length forms of Sho being less than $20 \mathrm{kDa}$, they are considerably below a cutoff of 30-60$\mathrm{kDa}$ for passive diffusion into nucleus [64]. The notion of divergence in function following from different propensity to relocalize under conditions of compromised proteasomal activity can be reconciled with results of a genetic interrogation, namely the viability of $\operatorname{Prnp}^{0 / 0}+$ $\operatorname{Sprn}^{0 / 0}$ double knockout mice [13, 30].

Overarching goals in this area are to define the association between allelic forms of Sho and two varieties of Creutzfeldt-Jakob disease [65], the cause of coordinated changes in Sho and $\operatorname{PrP}^{\mathrm{C}}$ levels in scrapie disease, and the possible role of general clearance pathways for glycoproteins. An earlier notion derived from studies of scrapie infections is that Sho and $\operatorname{PrP}^{\mathrm{C}}[19,20]$ are substrates for the same, albeit unidentified protease system [20]. If this unidentified system were none other than the proteasomal system, then a number of observations on $\operatorname{PrP}^{\mathrm{C}}$ and $\operatorname{PrP}^{\mathrm{Sc}}$ and preclinical changes in infected animals might be tied together $[20,45-47,66]$. On the other hand, the divergent observations that prion infection diminishes net levels for Sho (and $\operatorname{PrP}^{\mathrm{C}}$ ) [20, 45], whereas proteasomal inhibition used here causes a balanced redistribution, suggest that this unifying logic is premature or an oversimplification. What is perhaps most surprising here is that studies with the intention to probe the proteostatic pathways degrading members of the mammalian PrP superfamily have revealed Sho not merely a passive substrate, but, with the varying location, as an indicator of proteostatic status. Our data point to engagement/non-engagement of the ER translocon machinery as the decision point for alternative targeting, suggesting that natural signal peptide polymorphisms in humans and sheep [65, 67] will impact the endpoints in the assays presented here and provide broader illumination on Sho biology.

Acknowledgements We thank S. Wohlgemuth for useful discussions.

Funding Information This work was supported by the Canadian Institutes of Health Research (CIHR; MOP137094). Instrumentation was supported by the Canada Foundation for Innovation. DW was supported by a Canada Research Chair (Tier 1).

\section{Compliance with Ethical Standards}

All animal handling protocols were in accordance with Canadian Council on Animal Care and University of Alberta institutional ethics review (protocol AUP00000356).

Conflict of Interest The authors declare that they have no conflicts of interest.
Open Access This article is distributed under the terms of the Creative Commons Attribution 4.0 International License (http:// creativecommons.org/licenses/by/4.0/), which permits unrestricted use, distribution, and reproduction in any medium, provided you give appropriate credit to the original author(s) and the source, provide a link to the Creative Commons license, and indicate if changes were made.

\section{References}

1. Cohen FE, Prusiner SB (1998) Pathologic conformations of prion proteins. Annu Rev Biochem 67:793-819

2. Carlson GA, Lovett M, Epstein CJ, Westaway D, Goodman PA, Marshall ST, Prusiner SB (1986) The prion gene complex: polymorphism of Prn-p and its linkage with agouti. XIVth Molecular and Biochemical Genetics Workshop, Bar Harbor, Maine

3. Hunter N, Hope J, McConnell I, Dickinson AG (1987) Linkage of the scrapie-associated fibril protein $(\operatorname{PrP})$ gene and Sinc using congenic mice and restriction fragment length polymorphism analysis. J Gen Virol 68:2711-2716

4. Westaway D, Goodman PA, Mirenda CA, McKinley MP, Carlson GA, Prusiner SB (1987) Distinct prion proteins in short and long scrapie incubation period mice. Cell 51:651-662

5. Büeler H, Aguzzi A, Sailer A, Greiner R-A, Autenried P, Aguet M, Weissmann C (1993) Mice devoid of PrP are resistant to scrapie. Cell 73:1339-1347

6. Wopfner F, Weidenhofer G, Schneider R, von Brunn A, Gilch S, Schwarz TF, Werner T, Schatzl HM (1999) Analysis of 27 mammalian and 9 avian PrPs reveals high conservation of flexible regions of the prion protein. J Mol Biol 289(5):1163-1178

7. Büeler H, Fischer M, Lang Y, Bluethmann H, Lipp HP, DeArmond SJ, Prusiner SB, Aguet M et al (1992) Normal development and behaviour of mice lacking the neuronal cell-surface PrP protein. Nature 356(6370):577-582

8. Shmerling D, Hegyi I, Fischer M, Blattler T, Brandner S, Götz J, Rulicke T, Flechsig E et al (1998) Expression of amino-terminally truncated $\operatorname{PrP}$ in the mouse leading to ataxia and specific cerebellar lesions. Cell 93:203-214

9. Premzl M, Sangiorgio L, Strumbo B, Marshall Graves JA, Simonic T, Gready JE (2003) Shadoo, a new protein highly conserved from fish to mammals and with similarity to prion protein. Gene 314:89102

10. Miesbauer M, Bamme T, Riemer C, Oidtmann B, Winklhofer KF, Baier M, Tatzelt J (2006) Prion protein-related proteins from zebrafish are complex glycosylated and contain a glycosylphosphatidylinositol anchor. Biochem Biophys Res Commun 341(1):218-224

11. Watts JC, Drisaldi B, Ng V, Yang J, Strome B, Horne P, Sy MS, Yoong L et al (2007) The CNS glycoprotein Shadoo has $\operatorname{PrP}(C)$ like protective properties and displays reduced levels in prion infections. EMBO J 26(17):4038-4050

12. Watts JC, Huo H, Bai Y, Ehsani S, Jeon AH, Shi T, Daude N, Lau A et al (2009) Interactome analyses identify ties of PrP and its mammalian paralogs to oligomannosidic N-glycans and endoplasmic reticulum-derived chaperones. PLoS Pathog 5(10):e1000608. https://doi.org/10.1371/journal.ppat.1000608

13. Daude N, Wohlgemuth S, Brown R, Pitstick R, Gapeshina H, Yang J, Carlson GA, Westaway D (2012) Knockout of the prion protein (PrP)-like Sprn gene does not produce embryonic lethality in combination with $\operatorname{PrP}(\mathrm{C})$-deficiency. Proc Natl Acad Sci U S A 109(23):9035-9040

14. Daude N, Ng V, Watts JC, Genovesi S, Glaves JP, Wohlgemuth S, Schmitt-Ulms G, Young H et al (2010) Wild-type Shadoo proteins 
convert to amyloid-like forms under native conditions. $\mathrm{J}$ Neurochem 113:92-104. https://doi.org/10.1111/j.1471-4159. 2010.06575.x

15. Li Q, Richard CA, Moudjou M, Vidic J (2015) Purification and refolding to amyloid fibrils of (His)6-tagged recombinant Shadoo protein expressed as inclusion bodies in E. coli. J Vis Exp (106): e53432. https://doi.org/10.3791/53432

16. Pepe A, Avolio R, Matassa DS, Esposito F, Nitsch L, Zurzolo C, Paladino S, Sarnataro D (2017) Regulation of sub-compartmental targeting and folding properties of the prion-like protein Shadoo. Sci Rep 7(1):3731. https://doi.org/10.1038/s41598-017-03969-2

17. Miyazawa K, Manuelidis L (2010) Agent-specific Shadoo responses in transmissible encephalopathies. J NeuroImmune Pharmacol 5:155-163. https://doi.org/10.1007/s11481-010-9191-1

18. Westaway D, Genovesi S, Daude N, Brown R, Lau A, Lee I, Mays CE, Coomaraswamy J et al (2011) Down-regulation of Shadoo in prion infections traces a pre-clinical event inversely related to $\operatorname{PrP}(\mathrm{Sc})$ accumulation. PLoS Pathog 7(11):e1002391. https://doi. org/10.1371/journal.ppat.1002391

19. Watts JC, Stohr J, Bhardwaj S, Wille H, Oehler A, Dearmond SJ, Giles K, Prusiner SB (2011) Protease-resistant prions selectively decrease Shadoo protein. PLoS Pathog 7(11):e1002382. https:// doi.org/10.1371/journal.ppat.1002382

20. Mays CE, Kim C, Haldiman T, van der Merwe J, Lau A, Yang J, Grams J, Di Bari MA et al (2014) Prion disease tempo determined by host-dependent substrate reduction. J Clin Invest 124(2):847858. https://doi.org/10.1172/JCI72241

21. Zhang J, Guo Y, Xie WL, Xu Y, Ren K, Shi Q, Zhang BY, Chen C et al (2014) Disruption of glycosylation enhances ubiquitinmediated proteasomal degradation of Shadoo in scrapie-infected rodents and cultured cells. Mol Neurobiol 49:1373-1384. https:// doi.org/10.1007/s12035-013-8612-6

22. Barmada SJ, Harris DA (2005) Visualization of prion infection in transgenic mice expressing green fluorescent protein-tagged prion protein. J Neurosci 25(24):5824-5832. https://doi.org/10.1523/ JNEUROSCI.1192-05.2005

23. Mironov A Jr, Latawiec D, Wille H, Bouzamondo-Bernstein E, Legname G, Williamson RA, Burton D, DeArmond SJ et al (2003) Cytosolic prion protein in neurons. J Neurosci 23(18): 7183-7193

24. Oglecka K, Lundberg P, Magzoub M, Goran Eriksson LE, Langel U, Graslund A (2008) Relevance of the N-terminal NLS-like sequence of the prion protein for membrane perturbation effects. Biochim Biophys Acta 1778(1):206-213. https://doi.org/10.1016/ j.bbamem.2007.09.034

25. Wang X, Wang F, Arterburn L, Wollmann R, Ma J (2006) The interaction between cytoplasmic prion protein and the hydrophobic lipid core of membrane correlates with neurotoxicity. J Biol Chem 281(19):13559-13565. https://doi.org/10.1074/jbc.M512306200

26. Pfeiffer NV, Dirndorfer D, Lang S, Resenberger UK, Restelli LM, Hemion C, Miesbauer M, Frank S et al (2013) Structural features within the nascent chain regulate alternative targeting of secretory proteins to mitochondria. EMBO J 32(7):1036-1051. https://doi. org/10.1038/emboj.2013.46

27. Toth E, Kulcsar PI, Fodor E, Ayaydin F, Kalmar L, Borsy AE, Laszlo L, Welker E (2013) The highly conserved, N-terminal (RXXX)8 motif of mouse Shadoo mediates nuclear accumulation. Biochim Biophys Acta 1833(5):1199-1211. https://doi.org/10. 1016/j.bbamcr.2013.01.020

28. Corley SM, Gready JE (2008) Identification of the RGG box motif in Shadoo: RNA-binding and signaling roles? Bioinform Biol Insights 2:383-400

29. Lau A, Mays CE, Genovesi S, Westaway D (2012) RGG repeats of PrP-like Shadoo protein bind nucleic acids. Biochemistry 51(45): 9029-9031. https://doi.org/10.1021/bi301395w
30. Daude N, Westaway D (2012) Shadoo/PrP (Sprn(0/0)/Prnp(0/0) ) double knockout mice: more than zeroes. Prion 6(5):420-424. https://doi.org/10.4161/pri.21867

31. Sarnataro D, Pepe A, Zurzolo C (2017) Cell biology of prion protein. Prog Mol Biol Transl Sci 150:57-82. https://doi.org/10.1016/ bs.pmbts.2017.06.018

32. Kang SG, Kim C, Cortez LM, Carmen Garza M, Yang J, Wille H, Sim VL, Westaway D et al (2016) Toll-like receptor-mediated immune response inhibits prion propagation. Glia 64(6):937-951. https://doi.org/10.1002/glia.22973

33. Race RE, Fadness LH, Chesebro B (1987) Characterization of scrapie infection in mouse neuroblastoma cells. J Gen Virol 68:13911399

34. Butler DA, Scott MRD, Bockman JM, Borchelt DR, Taraboulos A, Hsiao KK, Kingsbury DT, Prusiner SB (1988) Scrapie-infected murine neuroblastoma cells produce protease-resistant prion proteins. J Virol 62:1558-1564

35. Kisselev AF, Goldberg AL (2001) Proteasome inhibitors: from research tools to drug candidates. Chem Biol 8(8):739-758

36. Tsubuki S, Saito Y, Tomioka M, Ito H, Kawashima S (1996) Differential inhibition of calpain and proteasome activities by peptidyl aldehydes of di-leucine and tri-leucine. J Biochem 119(3):572-576

37. Kim HS, Montana V, Jang HJ, Parpura V, Kim JA (2013) Epigallocatechin gallate (EGCG) stimulates autophagy in vascular endothelial cells: a potential role for reducing lipid accumulation. J Biol Chem 288(31):22693-22705. https://doi.org/10.1074/jbc. M113.477505

38. Wu YT, Tan HL, Shui G, Bauvy C, Huang Q, Wenk MR, Ong CN, Codogno P et al (2010) Dual role of 3-methyladenine in modulation of autophagy via different temporal patterns of inhibition on class I and III phosphoinositide 3-kinase. J Biol Chem 285(14):10850 10861. https://doi.org/10.1074/jbc.M109.080796

39. Du Y, Yang D, Li L, Luo G, Li T, Fan X, Wang Q, Zhang X et al (2009) An insight into the mechanistic role of p53-mediated autophagy induction in response to proteasomal inhibition-induced neurotoxicity. Autophagy 5(5):663-675

40. Liu BQ, Du ZX, Zong ZH, Li C, Li N, Zhang Q, Kong DH, Wang HQ (2013) BAG3-dependent noncanonical autophagy induced by proteasome inhibition in HepG2 cells. Autophagy 9(6):905-916. https://doi.org/10.4161/auto.24292

41. Aguzzi A, Nuvolone M, Zhu C (2013) The immunobiology of prion diseases. Nat Rev Immunol 13(12):888-902. https://doi.org/ $10.1038 /$ nri3553

42. Heneka MT, Kummer MP, Latz E (2014) Innate immune activation in neurodegenerative disease. Nat Rev Immunol 14(7):463-477. https://doi.org/10.1038/nri3705

43. Pintado C, Gavilan MP, Gavilan E, Garcia-Cuervo L, Gutierrez A, Vitorica J, Castano A, Rios RM et al (2012) Lipopolysaccharideinduced neuroinflammation leads to the accumulation of ubiquitinated proteins and increases susceptibility to neurodegeneration induced by proteasome inhibition in rat hippocampus. $\mathrm{J}$ Neuroinflammation 9:87. https://doi.org/10.1186/1742-2094-9-87

44. Pintado C, Macias S, Dominguez-Martin H, Castano A, Ruano D (2017) Neuroinflammation alters cellular proteostasis by producing endoplasmic reticulum stress, autophagy activation and disrupting ERAD activation. Sci Rep 7(1):8100. https://doi.org/10.1038/ s41598-017-08722-3

45. Mays CE, van der Merwe J, Kim C, Haldiman T, McKenzie D, Safar JG, Westaway D (2015) Prion infectivity plateaus and conversion to symptomatic disease originate from falling precursor levels and increased levels of oligomeric PrPSc species. J Virol 89(24):12418-12426. https://doi.org/10.1128/JVI.02142-15

46. Kristiansen M, Deriziotis P, Dimcheff DE, Jackson GS, Ovaa H, Naumann H, Clarke AR, van Leeuwen FW et al (2007) Disease- 
associated prion protein oligomers inhibit the $26 \mathrm{~S}$ proteasome. Mol Cell 26(2):175-188. https://doi.org/10.1016/j.molcel.2007.04.001

47. McKinnon C, Goold R, Andre R, Devoy A, Ortega Z, Moonga J, Linehan JM, Brandner S et al (2016) Prion-mediated neurodegeneration is associated with early impairment of the ubiquitinproteasome system. Acta Neuropathol 131(3):411-425. https:// doi.org/10.1007/s00401-015-1508-y

48. Lloyd SE, Maytham EG, Pota H, Grizenkova J, Molou E, Uphill J, Hummerich H, Whitfield J et al (2009) HECTD2 is associated with susceptibility to mouse and human prion disease. PLoS Genet 5(2): e1000383. https://doi.org/10.1371/journal.pgen.1000383

49. Abdulrahman BA, Abdelaziz DH, Schatzl HM (2018) Autophagy regulates exosomal release of prions in neuronal cells. J Biol Chem 293(23):8956-8968. https://doi.org/10.1074/jbc.RA117.000713

50. Homma T, Ishibashi D, Nakagaki T, Fuse T, Mori T, Satoh K, Atarashi R, Nishida N (2015) Ubiquitin-specific protease 14 modulates degradation of cellular prion protein. Sci Rep 5:11028. https://doi.org/10.1038/srep11028

51. Tóth E, Welker E (2012) Comparison of anti-Shadoo antibodieswhere is the endogenous Shadoo protein? World Acad Sci Eng Technol. 6(11):975-977

52. Drisaldi B, Stewart RS, Adles C, Stewart LR, Quaglio E, Biasini E, Fioriti L, Chiesa R et al (2003) Mutant PrP is delayed in its exit from the endoplasmic reticulum, but neither wild-type nor mutant PrP undergoes retrotranslocation prior to proteasomal degradation. J Biol Chem 278(24):21732-21743

53. Ferris SP, Kodali VK, Kaufman RJ (2014) Glycoprotein folding and quality-control mechanisms in protein-folding diseases. Dis Model Mech 7(3):331-341. https://doi.org/10.1242/dmm.014589

54. Borgese $\mathrm{N}$ (2016) Getting membrane proteins on and off the shuttle bus between the endoplasmic reticulum and the Golgi complex. J Cell Sci 129(8):1537-1545. https://doi.org/10.1242/jcs.183335

55. Mays CE, Coomaraswamy J, Watts JC, Yang J, Ko KW, Strome B, Mercer RC, Wohlgemuth SL et al (2014) Endoproteolytic processing of the mammalian prion glycoprotein family. FEBS J 281(3): 862-876. https://doi.org/10.1111/febs. 12654

56. Mogensen TH (2009) Pathogen recognition and inflammatory signaling in innate immune defenses. Clin Microbiol Rev 22(2):240 273, Table of Contents. https://doi.org/10.1128/CMR.00046-08

57. Sarnataro D (2018) Attempt to untangle the prion-like misfolding mechanism for neurodegenerative diseases. Int J Mol Sci 19(10). https://doi.org/10.3390/ijms19103081

58. Jaegly A, Mouthon F, Peyrin JM, Camugli B, Deslys JP, Dormont D (1998) Search for a nuclear localization signal in the prion protein. Mol Cell Neurosci 11(3):127-133. https://doi.org/10.1006/ mone.1998.0675

59. Gu Y, Hinnerwisch J, Fredricks R, Kalepu S, Mishra RS, Singh N (2003) Identification of cryptic nuclear localization signals in the prion protein. Neurobiol Dis 12(2):133-149
60. Guo L, Kim HJ, Wang H, Monaghan J, Freyermuth F, Sung JC, O'Donovan K, Fare CM et al (2018) Nuclear-import receptors reverse aberrant phase transitions of RNA-binding proteins with prion-like domains. Cell 173(3):677-692 e620. https://doi.org/10. 1016/j.cell.2018.03.002

61. Hennig S, Kong G, Mannen T, Sadowska A, Kobelke S, Blythe A, Knott GJ, Iyer KS et al (2015) Prion-like domains in RNA binding proteins are essential for building subnuclear paraspeckles. J Cell Biol 210(4):529-539. https://doi.org/10.1083/jcb.201504117

62. Nunziante M, Ackermann K, Dietrich K, Wolf H, Gadtke L, Gilch S, Vorberg I, Groschup M et al (2011) Proteasomal dysfunction and endoplasmic reticulum stress enhance trafficking of prion protein aggregates through the secretory pathway and increase accumulation of pathologic prion protein. J Biol Chem 286(39):3394233953. https://doi.org/10.1074/jbc.M111.272617

63. Dron M, Dandoy-Dron F, Farooq Salamat MK, Laude H (2009) Proteasome inhibitors promote the sequestration of PrPSc into aggresomes within the cytosol of prion-infected CAD neuronal cells. J Gen Virol 90(Pt 8):2050-2060. https://doi.org/10.1099/vir. 0.010082-0

64. Timney BL, Raveh B, Mironska R, Trivedi JM, Kim SJ, Russel D, Wente SR, Sali A et al (2016) Simple rules for passive diffusion through the nuclear pore complex. J Cell Biol 215(1):57-76. https:// doi.org/10.1083/jcb.201601004

65. Beck JA, Campbell TA, Adamson G, Poulter M, Uphill JB, Molou E, Collinge J, Mead S (2008) Association of a null allele of SPRN with variant Creutzfeldt-Jakob disease. J Med Genet 45(12):813817. https://doi.org/10.1136/jmg.2008.061804

66. Deriziotis P, Andre R, Smith DM, Goold R, Kinghorn KJ, Kristiansen M, Nathan JA, Rosenzweig R et al (2011) Misfolded PrP impairs the UPS by interaction with the 20S proteasome and inhibition of substrate entry. EMBO J 30(15):3065-3077. https:// doi.org/10.1038/emboj.2011.224

67. Daude N, Wohlgemuth S, Rogaeva E, Farid AH, Heaton M, Westaway D (2009) Frequent missense and insertion/deletion polymorphisms in the ovine Shadoo gene parallel species-specific variation in PrP. PLoS One 4(8):e6538

Publisher's Note Springer Nature remains neutral with regard to jurisdictional claims in published maps and institutional affiliations. 